\title{
Physiological and Sanitary Attributes Evaluation of Organic Coriander Seeds Treated With Essential Oils
}

\author{
Ariadne Waureck ${ }^{1} \&$ Ana Dionisia da Luz Coelho Novembre ${ }^{2}$ \\ ${ }^{1}$ Post Graduate Program in Agronomy, State University of Ponta Grossa, Ponta Grossa, PR, Brazil \\ ${ }^{2}$ Crop Science Department, University of São Paulo, Piracicaba, SP, Brazil \\ Correspondence: Ariadne Waureck, Post Graduate Program in Agronomy, State University of Ponta Grossa, \\ General Carlos Cavalcanti Street, 4748, 84030-900, Uvaranas, Ponta Grossa, Paraná, Brazil. Tel: \\ 55-42-3220-3738. E-mail: ariadne.waureck@hotmail.com
}

Received: January 8, 2020

doi:10.5539/jas.v12n4p163
Accepted: February 9, $2020 \quad$ Online Published: March 15, 2020

URL: https://doi.org/10.5539/jas.v12n4p163

\begin{abstract}
For seeds organic production the control of fungi with chemical fungicides is not indicated, which requires the use of biological products. In this sense, the use of essential oils derived from plants is a possibility for microorganisms control. This study evaluated technical feasibility of applying the essential oils of clove, lemongrass, rosemary, eucalyptus, ginger and Tea tree, in concentrations of $500,1.000,1.500$ and $2.000 \mu \mathrm{L}^{-1}$ to organic coriander seeds of the Verdon variety, besides the control. At the beginning of storage and every 60 days the seeds were evaluated for water content, germination, germination velocity index and root emission, seedling emergence and seedling emergence speed index, to shoot length, rootlength, total length and sanity. The experimental design was a completely randomized (DCR), in a $6 \times 4+1$ factorial scheme, with six essential oils and four concentrations + control treatment, with four replications for germination and vigor analysis, and eight replications for sanitary analysis. With increasing concentration of essential oils, there was a linear reduction in germination and a reduction in the incidence of Alternaria sp. using clove and rosemary oils at a concentration of $500 \mu \mathrm{L} \mathrm{L}^{-1}$, eucalyptus at a concentration of $1.500 \mu \mathrm{L} \mathrm{L}^{-1}$ and ginger with $2.000 \mu \mathrm{L} \mathrm{L}^{-1}$. Therefore, it is possible to use clove and rosemary essential oils up to $500 \mu \mathrm{L} \mathrm{L}^{-1}$ to reduce the incidence of Alternaria sp. without causing significant reduction in germination.
\end{abstract}

Keywords: Coriandrum sativum, germination, vigor, sanity

\section{Introduction}

Coriander (Coriandrum sativum L.) is a leafy vegetable widely used in Brazilian cuisine, especially in the Northeast of Brazil, perhaps because of its adaptation, which according to Filgueira (2008) is a specie of tropical climate. It belongs to the same family as carrots, Apiaceae (Joly, 2002), and is a source of calcium, iron, vitamin $\mathrm{C}$ and $\mathrm{A}$. Its seed is of the diakene type (with two embryos). It is widely used as a condiment and medicinally, being its form of propagation by seeds (Wanderley Junior \& Nascimento, 2010).

Seed quality is essential to obtain vigorous, uniform seedlings and to achieve high productivity and quality, being fundamental for the producer, because the seed quality favors the production (Nascimento \& Pereira, 2007; Pereira et al., 2005).

Seed treatment is one of the important steps in maintaining physiological and sanitary quality, constituting one of the efficient and economical ways to control harmful pathogens to seeds. In organic seed production there is no use of chemicals such as fungicides, and control of seed-associated pathogens is a major concern for companies, which makes it essential to conduct research to establish alternative forms of treatment. Therefore, studies with plant extracts and essential oils aim to find active compounds with broad spectrum of action, low toxicity and reduced cost (Angioni et al., 2004; Rochete et al., 2003).

Essential oils are considered as natural volatile substances found in a wide variety of plants and are complex mixtures resulting from the interaction between different classes of compounds such as terpenes, monoterpenes, sesquiterpenes, aromatic compounds, phenols, aldehydes, ketones, alcohols and esters (Andrés et al., 2012; Aragão et al., 2015; Bakkali et al., 2008). Essential oils can be used as an effective method for disease control, as well as lower risk of environmental and food contamination caused by chemicals (Kamazeri et al., 2012; Xavier 
et al., 2012). According to Taiz and Zeiger (2013), essential oils are often found in vegetables, in all parts of the plant, in glandular trichomes, which protrude from the epidermis and act as a sign in relation to the toxicity of the plant. These oils can be extracted from vegetables through steam distillation. In addition, some secondary metabolites of plants, present in essential oils, can act on microorganisms and on the development of plants.

Post-harvest pathogen control can be achieved by applying essential oils (Boukaew et al., 2017). Various sources of essential oils include cinnamon, cloves, eucalyptus, peppermint, lemon balm and ginger (Nerilo et al., 2016; Tyagi \& Malik, 2011).

However, due to different compounds present in these oils, their interaction and concentration can interfere with cell development (Miranda et al., 2015). Flávio et al. (2014) found that clove basil essential oil reduced fungal infestation in sorghum seeds, but reduced their viability and vigor. In cabbage seeds, Amini et al. (2018) verified a reduction of Xanthomonas campestris with the use of Zataria multiflora essential oil, but there was a significant reduction in seed germination.

Storage is practically a mandatory step in a seed production program, being the main concern during the period the preservation of seed quality, as infections by microorganisms can reduce seed quality (Nascimento et al., 2006). Boukaew et al. (2017) found that fumigation of clove essential oil [Syzygium aromaticum (L.) Merr. \& L. M. Perry] can be applied to protect corn seeds from the fungus Aspergillus flavus during storage. However, results like these are still scarce in the literature due to the diversity of compounds present in essential oils.

The objective of this work was to evaluate the application effect of the essential oils of clove, lemongrass, rosemary, eucalyptus, ginger and Tea tree, in different concentrations, on the physiological and sanitary parameters of coriander organic seeds during storage.

\section{Method}

The freshly harvested organic Coriander (Coriandrum sativum L.) seeds of the Verdão variety supplied by the Mokiti Okada Foundation Research Center were produced in 2017 in the city of Ipeúna-SP. Product applications and seed analysis were performed at the Seed Analysis Laboratory of Ponta Grossa State University, Ponta Grossa, PR, Brazil.

Essential oils of clove [Eugenia caryophyllus (L.) Merrill \& Perry], lemongrass [Cymbopogon citrates (DC) Stapf.], rosemary (Rosmarinus officinalis L.), eucalyptus (Eucalyptus globules Labill.), ginger (Zingiber officinale Roscoe.) and Tea tree (Tea tree alternifólia Cheel.) were applied to the seeds at concentrations of 500; $1.000 ; 1.500$ and $2.000 \mu \mathrm{L} \mathrm{L}^{-1}$ plus $1 \%(\mathrm{v} / \mathrm{v})$ Tween 80 to facilitate emulsification of oils in distilled water (Brito et al., 2012), besides the control (no applications). The application of essential oils to seeds was by immersion for a period of three minutes. Then the seeds were placed on two sheets of sterile blotting paper for drying in a natural environment until they reached $6 \%$ of water. Subsequently, they were placed in aluminized bags for cold room storage at $10{ }^{\circ} \mathrm{C}$ and $55 \%$ relative humidity.

Seed quality evaluations were performed immediately after treatment and at 60, 120 and 180 days after storage.

\subsection{Determination of Water Content}

To determine the water content, the adapted greenhouse method of Brasil (2009a) was used. For this, 2.0 grams of seeds were placed in previously identified containers and weighed in precision scales. The containers were placed open in the oven at $105 \pm 3{ }^{\circ} \mathrm{C}$ for a period of 24 hours. After the drying period, the containers were capped and placed in a desiccator until cooled for weighing. The result was expressed as a percentage of water.

\subsection{Germination Test $(G)$}

Four repetitions of 50 seeds distributed on paper (Germitest), moistened with water, at a ratio of 2.5 times the dry paper weight were used. The paper rolls were placed in a germination chamber, where they remained at a constant temperature of $20 \pm 2{ }^{\circ} \mathrm{C}$, with evaluations on the $21^{\text {st }}$ day after sowing, according to Brasil (2009a). The result was expressed as a percentage of normal seedlings.

\subsection{Germination Test First Count (GFC)}

The number of normal seedlings was recorded on the $9^{\text {th }}$ day of germination test, according to Brasil (2009a). The result was expressed as a percentage of normal seedlings.

\subsection{Germination Speed Index (GSI)}

The germination speed index (GSI) was calculated from the data obtained in the germination test (item 2.2). The evaluations were conducted daily, at the same time from the day when normal seedlings first emerged, whose 
amount was recorded and these seedlings were removed from the paper. To calculate the GSI, the formula described by Maguire (1962) was used.

\subsection{Root Emission Index (REI)}

Root emission index (REI) was determined from seedlings obtained in the germination test (item 2.3). The evaluations were conducted daily, at the same time from the day when normal roots first appeared, whose amount was recorded. To calculate the REI, the formula described by Maguire (1962) was used.

\subsection{Seedling Emergence (SE)}

Four replicates of 50 seeds were sown in 200-cell plastic trays. The seeds were sown to a depth of $1 \mathrm{~cm}$ and one seed per cell was placed. The substrate used was composed of peat, soil concealers, vermiculite, charcoal and pine bark.

The substrate was moistened daily with water equivalent to $60 \%$ of its holding capacity, and the trays were randomly distributed inside the greenhouse at $25^{\circ} \mathrm{C}$ and $70 \%$ relative humidity. The evaluations were performed on the 21 st day after sowing and the results were expressed as percentage of emerged seedlings (Nakagawa, 1994).

\subsection{Seedling Length}

Seedling length was evaluated according to Nakagawa (1994). Four repetitions of 10 seeds sown on a line drawn in the upper third of the seed germination paper (Germitest), moistened with water, at 2.5 times the weight of dry paper were evaluated. They were then maintained at $20^{\circ} \mathrm{C}$, with shoot, root and seedling length evaluations on the $21^{\text {st }}$ day after sowing and the results were expressed in centimeters.

\subsection{Sanitary Parameter Evaluation}

To evaluate the sanitary parameter, 200 seeds ( 8 replicates of 25 seeds) were placed in plastic boxes, previously disinfected with sodium hypochlorite for 24 hours and cleaned with alcohol, on two sheets of moistened filter paper 2.5 times the weight of dry paper. The seeds were kept for seven days in a BOD incubation chamber, regulated at $20^{\circ} \mathrm{C}$ and daily photoperiod of 12 hours. The fungi presence evaluation in the seeds was performed at seven days after sowing, using magnifying glass and microscope, classifying the fungi by gender. The results were expressed as percentage of occurrence of the observed fungi (Brasil, 2009b).

\subsection{Statistical Analysis}

The experimental design was a completely randomized (DCR), in a $6 \times 4+1$ factorial scheme, with six essential oils and four concentrations + control treatment, with four replications for germination and vigor analysis, and eight replications for sanitary analysis.

Data were analyzed for variance analysis to verify the significance of the interaction of essential oil and concentration factors. Essential oil concentration data, when significant, were submitted to polynomial regression analysis, up to the third degree, and when significant for essential oil, the means were compared by Tukey test (5\%). When necessary, the percentage data were transformed into $\arcsin \sqrt{(x+0.5) / 100}$ and analyzes were performed with the aid of R Studio program.

The essential oils used for the research were analyzed for chemical composition in the chromatography laboratory of the Federal University of Minas Gerais (Table 1). The methodology used was High Resolution Gas Chromatography with an AGILENT $7820^{\mathrm{a}}$ gas chromatograph, column: HP-5 $30 \mathrm{~m} \times 0.32 \mathrm{~mm} \times 0.25 \mu \mathrm{m}$ (AGILENT). Temperature: Column: $50{ }^{\circ} \mathrm{C}(0 \mathrm{~min}), 3{ }^{\circ} \mathrm{C} / \mathrm{min}$ at $200{ }^{\circ} \mathrm{C}$. Injector: $220{ }^{\circ} \mathrm{C}$ Split: $1 / 50$. FID detector: $220^{\circ} \mathrm{C}$. Injection volume: $1 \mu \mathrm{l}$ (concentration $1.0 \%$ in chloroform). 
Table 1. Gas chromatography analysis of the essential oils of clove (Eugenia caryophyllus), lemongrass (Cymbopogon citratus), rosemary (Rosmarinus officinalis), ginger (Eucalyptus globulus) and Tea tree (Melaleuca alternifolia)

\begin{tabular}{|c|c|c|c|c|c|c|}
\hline Constituents (\%) & $\begin{array}{l}\text { Clove } \\
\text { (Eugenia } \\
\text { caryophyllus) }\end{array}$ & $\begin{array}{l}\text { Lemongrass } \\
\text { (Cymbopogon } \\
\text { citratus) }\end{array}$ & $\begin{array}{l}\text { Rosemary } \\
\text { (Rosmarinus } \\
\text { officinalis) }\end{array}$ & $\begin{array}{l}\text { Eucalyptus } \\
\text { (Eucalyptus } \\
\text { globulus) }\end{array}$ & $\begin{array}{l}\text { Ginger } \\
\text { (Zingiber } \\
\text { officinale) }\end{array}$ & $\begin{array}{l}\text { Tea tree } \\
\text { (Melaleuca } \\
\text { alternifolia) }\end{array}$ \\
\hline 1,8-cineole & & & 39.6 & 89.9 & & 1.4 \\
\hline Ar-curcumene & & & & & 15.2 & \\
\hline Camphene & & 0.2 & 0.9 & & 7.1 & \\
\hline Camphene & & & & & & 0.4 \\
\hline Camphor & & & 27.7 & & & \\
\hline Carveol & & 0.1 & & & & \\
\hline Cis-calameno & & & & & & 0.3 \\
\hline Citronellal & & 0.5 & & & & \\
\hline Crisantenol & & 1.0 & & & & \\
\hline Eugenol & 87.3 & & 0.6 & & & \\
\hline E- $\beta$-ocimene & & & & 0.6 & & \\
\hline Geraniol & 0.4 & 48.7 & & & & \\
\hline Geranyl acetate & & 0.9 & & & & \\
\hline Germacrene d & & & & & 3.0 & \\
\hline Sabinene hydrate & & & & & 3.0 & \\
\hline Limonene & & 0.3 & 22.0 & 1.5 & 4.0 & 2.2 \\
\hline Linalool & & 0.2 & 0.8 & & & \\
\hline Myrcene & & 0.6 & 0.8 & 2.3 & & 0.4 \\
\hline Neral & & 42.2 & & & & \\
\hline Caryophyllene oxide & 0.4 & 0.8 & & & & \\
\hline p-cimene & & & 1.6 & 0.2 & & 2.8 \\
\hline Methyl salicylate & 0.2 & & & & & \\
\hline Sesquifelandreno & & & & & 12.6 & \\
\hline Terpinen-4-ol & & & & & & 42.5 \\
\hline Terpinolene & & & & 0.1 & & 3.4 \\
\hline Trans verbenol & & 0.7 & & & & \\
\hline Viridiflorino & & & & & & 0.4 \\
\hline Zingiberene & & & & & 30.5 & \\
\hline Z- $\beta$-ocimene & & 0.1 & & 0.1 & & \\
\hline$\alpha$-copaene & 0.5 & & & & & \\
\hline$\alpha$-farnesene & & & & & 9.0 & \\
\hline$\alpha$-phellandrene & & & & & & 1.0 \\
\hline$\alpha$-humulene & 1.8 & 0.6 & & & & \\
\hline$\alpha$-pinene & & & 2.9 & 2.2 & 2.8 & 5.0 \\
\hline$\alpha$-terpinene & & & & 1.4 & & 10 \\
\hline$\alpha$-terpineol & & & & & & 7.3 \\
\hline$\alpha$-thujene & & & & & & 0.3 \\
\hline$\beta$-bisabolene & & & & & 4.0 & \\
\hline$\beta$-caryophyllene & 9.3 & 0.7 & 0.8 & & & \\
\hline$\beta$-gurjunene & & & & & & 0.2 \\
\hline$\beta$-pinene & & & 1.5 & 1.6 & & 0.4 \\
\hline$\gamma$-muurolene & & 0.2 & & & & \\
\hline$\gamma$-terpinene & & 0.3 & & & & 20.4 \\
\hline Others & 0.4 & 1.5 & 0.8 & 0.3 & 8.7 & 1.7 \\
\hline
\end{tabular}

\section{Results}

For some variables there was interaction for the factors essential oil and concentration when performed the analysis of variance (ANOVA) for coriander seeds. The results related to the first count of coriander seed germination test ( 9 days after sowing) indicated that there was no statistically significant difference, due to the 
application of oils whose concentration was $500 \mu \mathrm{L} \mathrm{L}^{-1}$, from post-harvest to 60 days after storage (DAS) (Table 2).

This result was also observed for concentrations of $1.000 \mu \mathrm{L}^{-1}$ in seeds stored up to 60 days. At the concentration of $1.000 \mu \mathrm{L} \mathrm{L}^{-1}$ in the seeds without storage submitted to the application of eucalyptus, ginger, clove and Tea tree oils the germination was statistically superior to the treatments with lemongrass and rosemary oils in the same concentration. For the first germination test count, the treatment with eucalyptus essential oil was statistically superior when compared to other treatments results (Table 2).

Table 2. First germination test count (\%) of coriander seeds submitted to different concentrations of essential oils in post-harvest, 60, 120 and 180 days after storage (DAS)

\begin{tabular}{|c|c|c|c|c|c|c|c|c|c|}
\hline \multirow{4}{*}{$\begin{array}{l}\text { Essential oil } \\
\text { Clove }\end{array}$} & \multicolumn{9}{|c|}{ First count (\%)-Initial post-harvest } \\
\hline & \multicolumn{9}{|c|}{ Concentration $\left(\mu 1 \mathrm{~L}^{-1}\right)$} \\
\hline & 0 & \multicolumn{2}{|l|}{500} & \multicolumn{2}{|c|}{1.000} & \multicolumn{2}{|c|}{1.500} & \multicolumn{2}{|c|}{2.000} \\
\hline & $45^{\mathrm{ns}}$ & 44 & ns & 43 & $a b^{*}$ & 38 & $\mathrm{a}$ & 36 & $\mathrm{a}$ \\
\hline Lemongrass & 45 & 42 & & 37 & $\mathrm{c}$ & 21 & $\mathrm{~b}$ & 12 & $\mathrm{~b}$ \\
\hline Rosemary & 45 & 41 & & 37 & $\mathrm{c}$ & 39 & $\mathrm{a}$ & 39 & $\mathrm{a}$ \\
\hline Eucalyptus & 45 & 43 & & 42 & $\mathrm{ab}$ & 36 & $\mathrm{a}$ & 36 & $\mathrm{a}$ \\
\hline Ginger & 45 & 42 & & 40 & $\mathrm{ab}$ & 39 & $\mathrm{a}$ & 37 & $\mathrm{a}$ \\
\hline Tea tree & 45 & 45 & & 44 & a & 40 & $\mathrm{a}$ & 40 & $\mathrm{a}$ \\
\hline \multicolumn{10}{|l|}{$60 D A S$} \\
\hline Clove & 41 ns & 42 & ns & 38 & & 37 & $\mathrm{a}$ & 36 & $\mathrm{a}$ \\
\hline Lemongrass & 41 & 40 & & 38 & & 20 & $\mathrm{~b}$ & 12 & $\mathrm{~b}$ \\
\hline Rosemary & 41 & 40 & & 37 & & 38 & $\mathrm{a}$ & 38 & $\mathrm{a}$ \\
\hline Eucalyptus & 41 & 41 & & 39 & & 37 & $\mathrm{a}$ & 36 & $\mathrm{a}$ \\
\hline Ginger & 41 & 41 & & 38 & & 37 & $\mathrm{a}$ & 36 & $\mathrm{a}$ \\
\hline Tea tree & 41 & 40 & & 39 & & 39 & $\mathrm{a}$ & 38 & $\mathrm{a}$ \\
\hline \multicolumn{10}{|l|}{$120 \mathrm{DAS}$} \\
\hline Clove & 36 ns & 24 & $\mathrm{~b}$ & 25 & $\mathrm{ab}$ & 25 & $\mathrm{ab}$ & 11 & $\mathrm{~d}$ \\
\hline Lemongrass & 36 & 27 & $\mathrm{ab}$ & 21 & $\mathrm{~b}$ & 21 & $\mathrm{~b}$ & 9 & $\mathrm{~d}$ \\
\hline Rosemary & 36 & 36 & $\mathrm{a}$ & 34 & a & 33 & $\mathrm{a}$ & 31 & $\mathrm{ab}$ \\
\hline Eucalyptus & 36 & 35 & $\mathrm{a}$ & 34 & a & 25 & $\mathrm{ab}$ & 24 & $\mathrm{bc}$ \\
\hline Ginger & 36 & 36 & $\mathrm{a}$ & 36 & $\mathrm{a}$ & 35 & $\mathrm{a}$ & 34 & $\mathrm{a}$ \\
\hline Tea tree & 36 & 36 & $\mathrm{a}$ & 34 & a & 29 & $\mathrm{ab}$ & 16 & $\mathrm{~cd}$ \\
\hline \multicolumn{10}{|l|}{$180 \mathrm{DAS}$} \\
\hline Clove & $14 \mathrm{~b}$ & & & & & & & & \\
\hline Lemongrass & $10 \mathrm{c}$ & & & & & & & & \\
\hline Rosemary & $13 \mathrm{~b}$ & & & & & & & & \\
\hline Eucalyptus & $18 \mathrm{a}$ & & & & & & & & \\
\hline Ginger & $14 \mathrm{~b}$ & & & & & & & & \\
\hline Tea tree & $13 \mathrm{~b}$ & & & & & & & & \\
\hline
\end{tabular}

Note. *Means followed by the same letter in the column, within each storage period, do not differ statistically by Tukey test at 5\% significance; $n s=$ not significant.

With increasing concentrations of essential oils applied to coriander seeds, there was a significant and linear reduction for the first post-harvest germination test count in the applications of clove, ginger and eucalyptus essential oils. At 60 DAS only the application of lemongrass oil had statistically significant variation and at 120 DAS there was a linear reduction for the germination test first count with the application of clove, lemongrass, eucalyptus and Tea tree essential oils. At 180 DAS there was a linear reduction in coriander seed germination with the application of essential oils (Figure 1). 

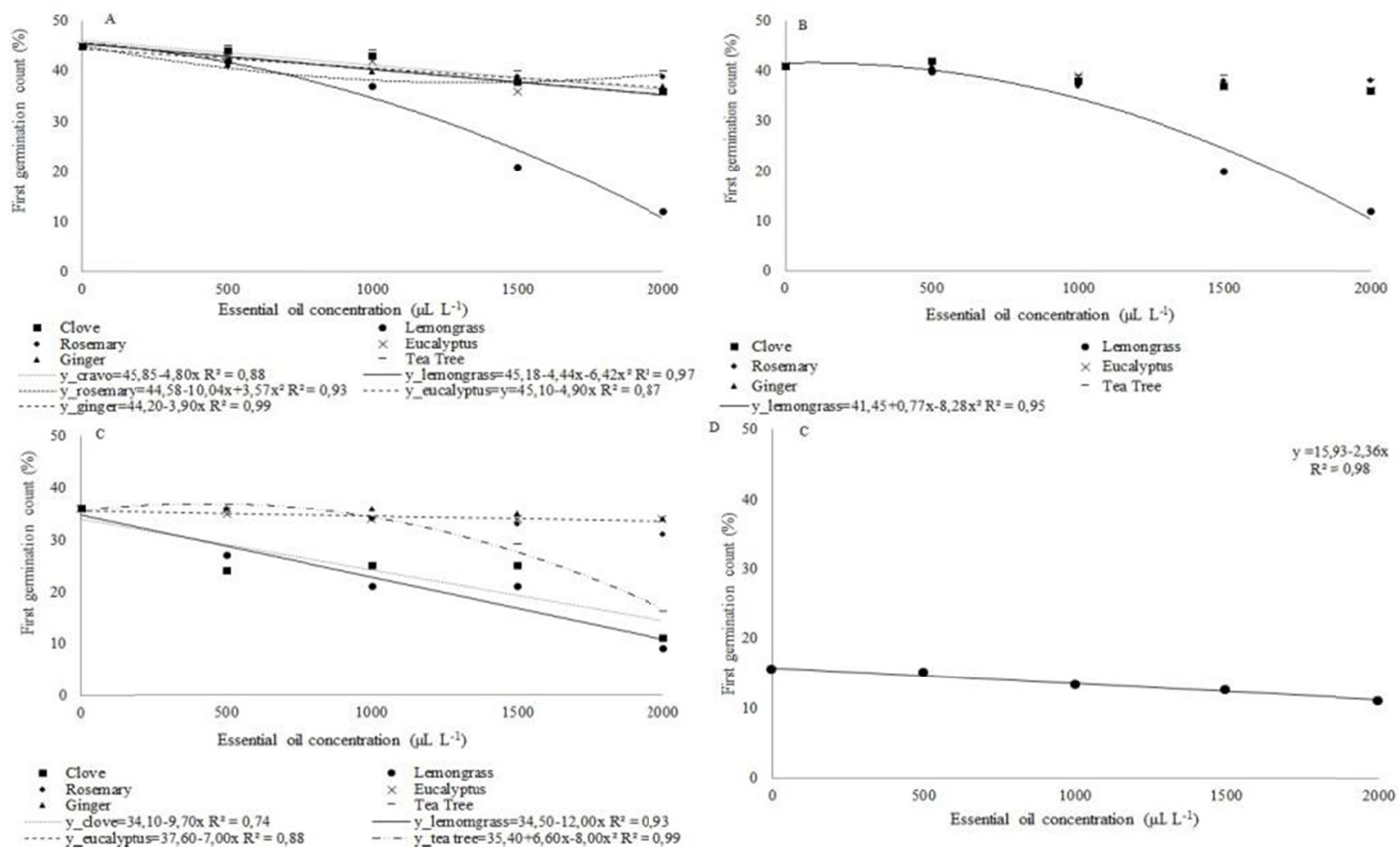

Figure 1. Regression analysis of the first germination count (\%) of coriander seeds submitted to different concentrations of essential oils (A), 60 (B), 120 (C) and 180 (D) days after storage (DAS).

For the germination test results, there was no significant interaction between the analyzed factors (Table 3 ). Seed germination was $76 \%$ in post-harvest for control treatment seeds.

Table 3. Germination (\%) of coriander seeds submitted to different concentrations of essential oils in post-harvest, 60, 120 and 180 days after storage (DAS)

\begin{tabular}{|c|c|c|c|c|}
\hline \multirow{3}{*}{ Essential oil } & \multicolumn{4}{|c|}{ Germination (\%) } \\
\hline & \multicolumn{4}{|c|}{ Days after storage (DAS) } \\
\hline & 0 & 60 & 120 & 180 \\
\hline Clove & $75 a^{*}$ & $69 \mathrm{a}$ & $64 \mathrm{a}$ & $59 \mathrm{a}$ \\
\hline Lemongrass & $68 \mathrm{~b}$ & $63 \mathrm{~b}$ & $51 \mathrm{~b}$ & $51 \mathrm{~b}$ \\
\hline Rosemary & $71 \mathrm{ab}$ & $70 \mathrm{a}$ & $63 \mathrm{a}$ & $62 \mathrm{a}$ \\
\hline Eucalyptus & $72 \mathrm{a}$ & $71 \mathrm{a}$ & $67 \mathrm{a}$ & $64 \mathrm{a}$ \\
\hline Ginger & $73 \mathrm{a}$ & $72 \mathrm{a}$ & $66 \mathrm{a}$ & $65 \mathrm{a}$ \\
\hline Tea tree & $73 \mathrm{a}$ & $70 \mathrm{a}$ & $62 \mathrm{a}$ & $60 \mathrm{a}$ \\
\hline
\end{tabular}

Note. *Means followed by the same letter in the column do not differ statistically from each other by the Tukey test at $5 \%$ significance.

In the post-harvest period, the germination percentage of seeds in which the eucalyptus, ginger, clove and Tea tree essential oils were applied was statistically higher than those treated with lemongrass essential oil. From 60 DAS, seeds with rosemary essential oil also showed superior germination to those treated with lemongrass essential oil (Figure 2). 

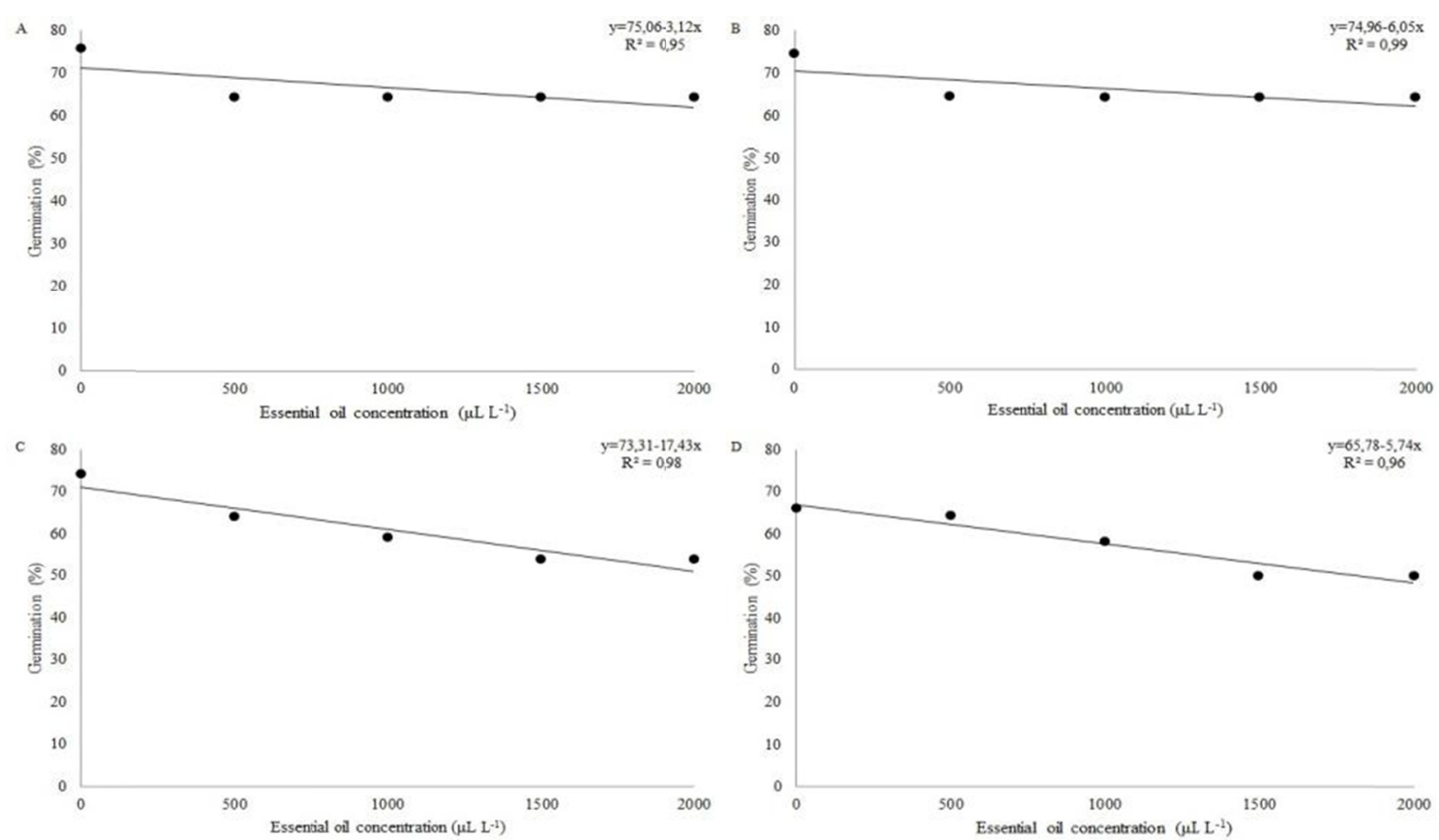

Figure 2. Regression analysis of germination (\%) of coriander seeds submitted to different post-harvest essential oil concentrations (A), 60 (B), 120 (C) and 180 (D) days after storage (DAS)

There was a linear reduction in the GSI result of coriander seeds with increasing concentrations of eucalyptus, ginger and clove essential oils in post-harvest. At 60 DAS, only the use of lemongrass oil was significant. At 120 DAS, there was a linear GSI reduction of coriander seeds with application of clove, eucalyptus and lemongrass essential oils (Figure 3).
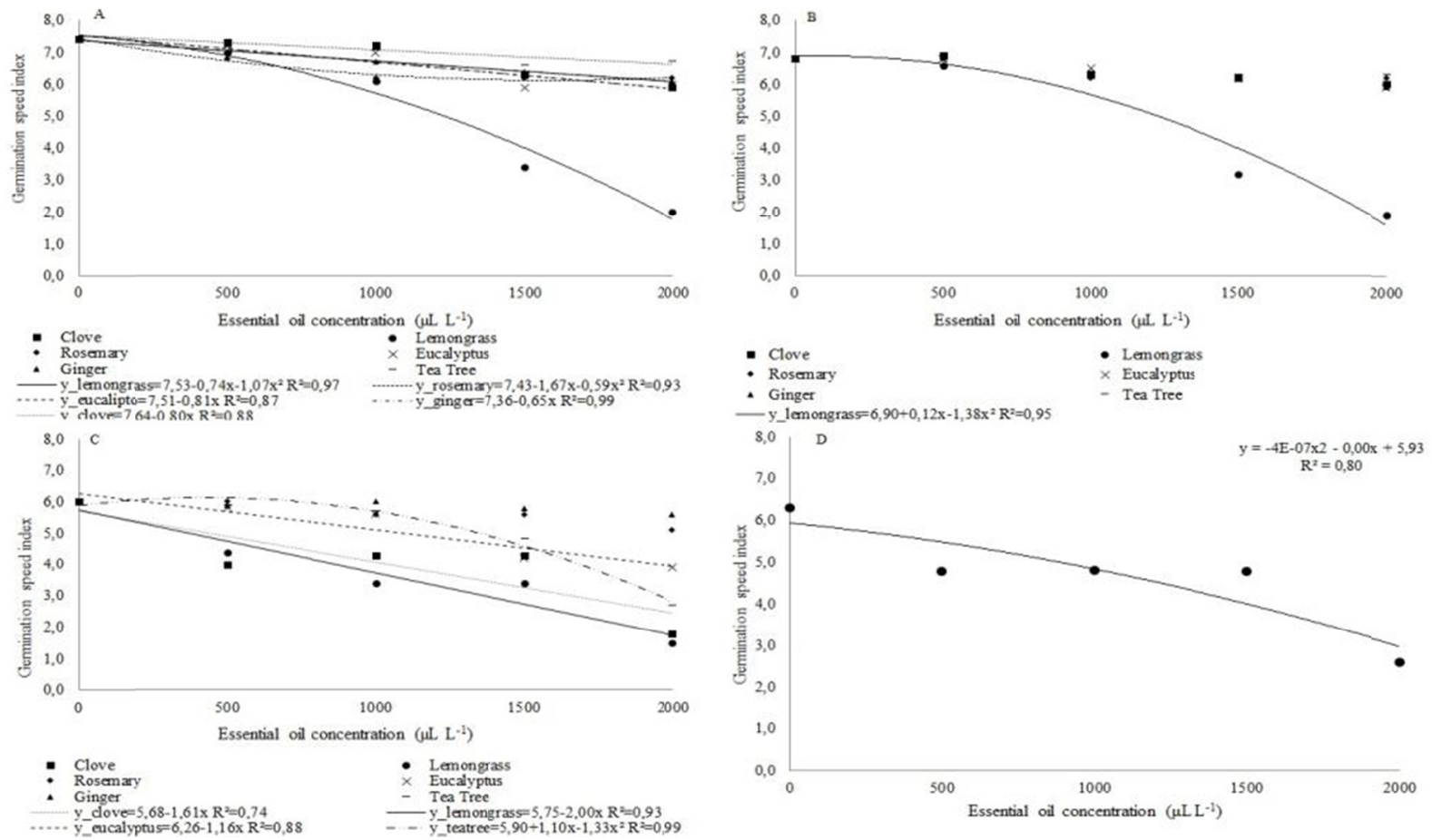

Figure 3. Regression analysis of the germination speed index (GSI) of coriander seeds submitted to the application of different post-harvest essential oil concentrations (A), 60 (B), 120 (C) and 180 (D) days after storage (DAS) 
For the germination speed index (GSI) the interaction between concentration and type of essential oil was significant up to 120 DAS. For seeds treated shortly in post-harvest and stored up to 60 days at a concentration of $500 \mu \mathrm{L} \mathrm{L}^{-1}$, the results showed no significant differences regarding GSI. With the application of $1.000 \mu \mathrm{L} \mathrm{L}$ of $^{-1}$ essential oils post-harvest and at 120 DAS, GSI results for Tea tree and clove essential oils were statistically superior to rosemary and lemongrass essential oils. However, the application of lemongrass oil at concentrations of 1.500 and $2.000 \mu \mathrm{L}^{-1}$ caused significant reduction of GSI in relation to the other treatments, maintained until 180 days of storage (Table 4 ).

Table 4. Germination speed index (GSI) of coriander seeds subjected to different concentrations of essential oils in post-harvest, 60, 120 and 180 days after storage (DAS)

\begin{tabular}{|c|c|c|c|c|c|c|c|c|c|c|}
\hline \multirow{3}{*}{ Essential oil } & \multicolumn{10}{|c|}{ GSI-Initial post-harvest } \\
\hline & \multicolumn{10}{|c|}{ Concentration $\left(\mu 1 \mathrm{~L}^{-1}\right)$} \\
\hline & \multicolumn{2}{|l|}{0} & \multicolumn{2}{|l|}{500} & \multicolumn{2}{|c|}{1.000} & \multicolumn{2}{|c|}{1.500} & \multicolumn{2}{|c|}{2.000} \\
\hline Clove & 7.4 & ns & 7.3 & ns & 7.2 & $a b^{*}$ & 6.3 & $\mathrm{a}$ & 5.9 & $\mathrm{a}$ \\
\hline Lemongrass & 7.4 & & 7.0 & & 6.1 & $\mathrm{c}$ & 3.4 & $\mathrm{~b}$ & 2.0 & $\mathrm{~b}$ \\
\hline Rosemary & 7.4 & & 6.8 & & 6.2 & $\mathrm{bc}$ & 6.2 & $\mathrm{a}$ & 6.2 & $\mathrm{a}$ \\
\hline Eucalyptus & 7.4 & & 7.2 & & 7.0 & $a b c$ & 5.9 & $\mathrm{a}$ & 6.0 & $\mathrm{a}$ \\
\hline Ginger & 7.4 & & 7.0 & & 6.7 & $a b c$ & 6.4 & $\mathrm{a}$ & 6.1 & $\mathrm{a}$ \\
\hline Tea tree & 7.4 & & 7.4 & & 7.3 & $\mathrm{a}$ & 6.6 & $\mathrm{a}$ & 6.7 & a \\
\hline \multicolumn{11}{|l|}{$60 D A S$} \\
\hline Clove & 6.8 & ns & 6.9 & ns & 6.3 & ns & 6.2 & $\mathrm{a}$ & 6.0 & $\mathrm{a}$ \\
\hline Lemongrass & 6.8 & & 6.6 & & 6.3 & & 3.2 & $\mathrm{~b}$ & 1.9 & $b$ \\
\hline Rosemary & 6.8 & & 6.6 & & 6.2 & & 6.2 & $\mathrm{a}$ & 6.2 & $\mathrm{a}$ \\
\hline Eucalyptus & 6.8 & & 6.8 & & 6.5 & & 6.2 & $\mathrm{a}$ & 5.9 & $\mathrm{a}$ \\
\hline Ginger & 6.8 & & 6.8 & & 6.3 & & 6.2 & $\mathrm{a}$ & 5.9 & $\mathrm{a}$ \\
\hline Tea tree & 6.8 & & 6.7 & & 6.4 & & 6.3 & $\mathrm{a}$ & 6.3 & $\mathrm{a}$ \\
\hline \multicolumn{11}{|l|}{$120 \mathrm{DAS}$} \\
\hline Clove & 6.0 & ns & 4.0 & $\mathrm{~b}$ & 4.3 & $a b$ & 4.3 & $a b$ & 1.8 & $\mathrm{~d}$ \\
\hline Lemongrass & 6.0 & & 4.4 & $\mathrm{ab}$ & 3.4 & $\mathrm{~b}$ & 3.4 & $\mathrm{~b}$ & 1.5 & $\mathrm{~d}$ \\
\hline Rosemary & 6.0 & & 6.0 & $\mathrm{a}$ & 5.6 & $\mathrm{a}$ & 5.6 & $\mathrm{a}$ & 5.1 & $a b$ \\
\hline Eucalyptus & 6.0 & & 5.8 & $\mathrm{a}$ & 5.6 & $\mathrm{a}$ & 4.2 & $a b$ & 3.9 & $\mathrm{bc}$ \\
\hline Ginger & 6.0 & & 5.9 & $\mathrm{a}$ & 6.0 & $\mathrm{a}$ & 5.8 & $\mathrm{a}$ & 5.6 & $\mathrm{a}$ \\
\hline Tea tree & 6.0 & & 5.9 & $\mathrm{a}$ & 5.7 & $\mathrm{a}$ & 4.8 & $a b$ & 2.7 & $\mathrm{~cd}$ \\
\hline \multicolumn{11}{|l|}{$180 D A S$} \\
\hline Clove & 2.3 & $\mathrm{~b}$ & & & & & & & & \\
\hline Lemongrass & 1.6 & $\mathrm{c}$ & & & & & & & & \\
\hline Rosemary & 2.2 & $\mathrm{~b}$ & & & & & & & & \\
\hline Eucalyptus & 2.9 & $\mathrm{a}$ & & & & & & & & \\
\hline Ginger & 2.4 & $\mathrm{~b}$ & & & & & & & & \\
\hline Tea tree & 2.1 & $\mathrm{~b}$ & & & & & & & & \\
\hline
\end{tabular}

Note. *Means followed by the same letter in the column, within each storage period, do not differ statistically by Tukey test at $5 \%$ significance; ns $=$ not significant.

There was significant interaction for essential oil and concentration for root emission index (REI) up to 120 DAS. The results were similar to those found in the GSI. From post-harvest to 120 days of storage, REI results with the application of essential oils at a concentration of $500 \mu \mathrm{L}^{-1}$ showed no significant differences. With the application of $1.000 \mu \mathrm{L} \mathrm{L}^{-1}$, treatment with Tea tree essential oil resulted in higher REI than rosemary and lemongrass essential oil treatments in post-harvest. No differences were found in seeds stored up to 60 days when treated with these essential oils and at this concentration (Table 5).

The REI result was statistically lower for the application of lemongrass Essential Oil at concentrations of 1.500 and $2.000 \mu \mathrm{L}^{-1}$ compared to the other results and maintained until 60 days of storage. At $120 \mathrm{DAS}$ lemongrass 
essential oils at concentrations of $1.000,1.500$ and $2.000 \mu \mathrm{L}^{-1}$ and clove with $2.000 \mu 1 \mathrm{~L}^{-1}$ resulted in statistically lower ESI than other treatments. The interaction between concentration and essential oil was not significant for REI at 180 DAS, however, there were significant differences for each variable analyzed separately. The seeds treated with eucalyptus essential oil showed a statistically higher REI than clove, lemongrass, rosemary, ginger and Tea tree oil applications (Table 5).

Table 5. Root emission index (REI) of coriander seedlings subjected to different concentrations of essential oils in post-harvest, 60, 120 and 180 days after storage (DAS)

\begin{tabular}{|c|c|c|c|c|c|c|c|c|c|c|}
\hline \multirow{3}{*}{ Essential oil } & \multicolumn{10}{|c|}{ REI-Initial post-harvest } \\
\hline & \multicolumn{10}{|c|}{ Concentration $\left(\mu l \mathrm{~L}^{-1}\right)$} \\
\hline & \multicolumn{2}{|l|}{0} & \multicolumn{2}{|l|}{500} & \multicolumn{2}{|c|}{1.000} & \multicolumn{2}{|c|}{1.500} & \multicolumn{2}{|c|}{2.000} \\
\hline Clove & 11.1 & ns & 11.0 & ns & 10.9 & $a b^{*}$ & 9.5 & $\mathrm{a}$ & 8.9 & $\mathrm{a}$ \\
\hline Lemongrass & 11.1 & & 10.5 & & 9.1 & $\mathrm{c}$ & 5.1 & $\mathrm{~b}$ & 3.0 & $\mathrm{~b}$ \\
\hline Rosemary & 11.1 & & 10.3 & & 9.2 & $\mathrm{bc}$ & 9.6 & a & 9.6 & $\mathrm{a}$ \\
\hline Eucalyptus & 11.1 & & 10.8 & & 10.5 & $a b c$ & 8.9 & $\mathrm{a}$ & 9.0 & $\mathrm{a}$ \\
\hline Ginger & 11.1 & & 10.6 & & 10.0 & $a b c$ & 9.6 & $\mathrm{a}$ & 9.1 & $\mathrm{a}$ \\
\hline Tea tree & 11.1 & & 11.1 & & 11.0 & $\mathrm{a}$ & 9.9 & a & 10.0 & $\mathrm{a}$ \\
\hline \multicolumn{11}{|l|}{$60 D A S$} \\
\hline Clove & 10.3 & ns & 10.3 & ns & 9.4 & ns & 9.3 & a & 9.0 & $\mathrm{a}$ \\
\hline Lemongrass & 10.3 & & 9.9 & & 9.4 & & 4.9 & $\mathrm{~b}$ & 2.3 & $\mathrm{~b}$ \\
\hline Rosemary & 10.3 & & 9.9 & & 9.3 & & 9.3 & $\mathrm{a}$ & 9.3 & $\mathrm{a}$ \\
\hline Eucalyptus & 10.3 & & 10.1 & & 9.8 & & 9.3 & $\mathrm{a}$ & 8.9 & $\mathrm{a}$ \\
\hline Ginger & 10.3 & & 10.1 & & 9.5 & & 9.3 & $\mathrm{a}$ & 8.9 & $\mathrm{a}$ \\
\hline Tea tree & 10.3 & & 10.0 & & 9.6 & & 9.6 & $\mathrm{a}$ & 9.5 & $\mathrm{a}$ \\
\hline \multicolumn{11}{|l|}{$120 \mathrm{DAS}$} \\
\hline Clove & 9.0 & ns & 6.0 & $a b$ & 6.3 & $a b$ & 6.3 & $a b$ & 2.3 & $\mathrm{c}$ \\
\hline Lemongrass & 9.0 & & 6.6 & $a b$ & 5.1 & $\mathrm{~b}$ & 5.1 & $\mathrm{~b}$ & 2.3 & $\mathrm{c}$ \\
\hline Rosemary & 9.0 & & 9.0 & $\mathrm{a}$ & 8.4 & $\mathrm{a}$ & 8.2 & $\mathrm{a}$ & 7.6 & $a b$ \\
\hline Eucalyptus & 9.0 & & 8.8 & $\mathrm{a}$ & 8.4 & $\mathrm{a}$ & 6.3 & $a b$ & 5.9 & $\mathrm{~b}$ \\
\hline Ginger & 9.0 & & 8.9 & $\mathrm{a}$ & 9.0 & $\mathrm{a}$ & 8.8 & $\mathrm{a}$ & 8.4 & $\mathrm{~b}$ \\
\hline Tea tree & 9.0 & & 8.9 & $\mathrm{a}$ & 8.5 & $\mathrm{a}$ & 7.1 & $a b$ & 8.4 & $\mathrm{a}$ \\
\hline \multicolumn{11}{|l|}{$180 \mathrm{DAS}$} \\
\hline Clove & 3.2 & $\mathrm{~b}$ & & & & & & & & \\
\hline Lemongrass & 2.2 & $\mathrm{c}$ & & & & & & & & \\
\hline Rosemary & 3.1 & $\mathrm{~b}$ & & & & & & & & \\
\hline Eucalyptus & 4.2 & $\mathrm{a}$ & & & & & & & & \\
\hline Ginger & 3.4 & $\mathrm{~b}$ & & & & & & & & \\
\hline Tea tree & 3.1 & $\mathrm{~b}$ & & & & & & & & \\
\hline
\end{tabular}

Note. *Means followed by the same letter in the column, within each storage period, do not differ statistically by Tukey test at 5\% significance; ns = not significant.

Coriander seedling emergence was also influenced by the application of essential oils. There was a significant interaction between the concentration and essential oil factors in post-harvest seed and storage of 120 to 180 days. In post-harvest, there was no significant difference in seeds treated with essential oils at concentrations of 500, $1.000 \mu \mathrm{L} \mathrm{L}^{-1}$ and control treatment. These results were also observed at 120 and 180 DAS (Table 6).

With 1.500 and $2.000 \mu \mathrm{L} \mathrm{L}^{-1}$ of clove, rosemary, eucalyptus and Tea tree essential oils the results of seedling emergence were higher than those treated with ginger and lemongrass essential oils at the same concentrations. At $120 \mathrm{DAS}$, only at the concentration of $2.000 \mu \mathrm{L}^{-1}$ there was significant variation, and the use of lemongrass oil was detrimental to seedling emergence. This was also observed at 180 DAS for concentrations of 1.500 and 2.000 $\mu \mathrm{L} \mathrm{L}^{-1}$ (Table 6). 
There was a linear reduction in REI with increasing concentrations of eucalyptus, clove and ginger essential oils in post-harvest. At 60 DAS only the application of lemongrass essential oil adjusted to the quadratic model At 120 DAS with the application of clove and eucalyptus essential oils the seeds showed linear reduction of REI with increasing concentrations and at 180 DAS there was adjustment to the quadratic regression model, according to the regression equation derivation, the concentration of $818.96 \mu \mathrm{L} \mathrm{L}^{-1}$ caused a REI reduction (Figure 4).

Table 6. Emergence (\%) of coriander seedlings submitted to different concentrations of essential oils in post-harvest, 60, 120 and 180 days after storage (DAS)

\begin{tabular}{|c|c|c|c|c|c|c|c|c|c|c|}
\hline \multirow{4}{*}{$\begin{array}{l}\text { Essential oil } \\
\text { Clove }\end{array}$} & \multicolumn{10}{|c|}{ Seedling Emergency (\%)-Initial post-harvest } \\
\hline & \multicolumn{10}{|c|}{ Concentration $\left(\mu 1 \mathrm{~L}^{-1}\right)$} \\
\hline & \multicolumn{2}{|l|}{0} & \multicolumn{2}{|c|}{500} & \multicolumn{2}{|c|}{1.000} & \multicolumn{2}{|c|}{1.500} & \multicolumn{2}{|c|}{2.000} \\
\hline & 73 & ns & 69 & $\begin{array}{c}\mathrm{ns} \\
\mathrm{ns}\end{array}$ & 68 & $\mathrm{~ns}$ & 64 & a8 & 61 & $\overline{\mathrm{a}}$ \\
\hline Lemongrass & 73 & & 64 & & 63 & & 32 & $\mathrm{c}$ & 29 & $\mathrm{c}$ \\
\hline Rosemary & 73 & & 73 & & 72 & & 69 & $\mathrm{a}$ & 64 & a \\
\hline Eucalyptus & 73 & & 66 & & 65 & & 65 & $\mathrm{a}$ & 57 & a \\
\hline Ginger & 73 & & 71 & & 63 & & 42 & $\mathrm{~b}$ & 42 & b \\
\hline Tea tree & 73 & & 71 & & 64 & & 60 & $\mathrm{a}$ & 57 & $\mathrm{a}$ \\
\hline \multicolumn{11}{|l|}{$60 D A S$} \\
\hline Clove & 59 & $\mathrm{a}$ & & & & & & & & \\
\hline Lemongrass & 45 & $\mathrm{~b}$ & & & & & & & & \\
\hline Rosemary & 58 & $\mathrm{a}$ & & & & & & & & \\
\hline Eucalyptus & 60 & $\mathrm{a}$ & & & & & & & & \\
\hline Ginger & 60 & $\mathrm{a}$ & & & & & & & & \\
\hline Tea tree & 56 & $\mathrm{a}$ & & & & & & & & \\
\hline \multicolumn{11}{|l|}{$120 D A S$} \\
\hline Clove & 62 & ns & 60 & ns & 58 & ns & 55 & $\mathrm{~ns}$ & 53 & $\mathrm{a}$ \\
\hline Lemongrass & 62 & & 60 & & 59 & & 53 & & 37 & b \\
\hline Rosemary & 62 & & 61 & & 59 & & 57 & & 52 & $\mathrm{a}$ \\
\hline Eucalyptus & 62 & & 58 & & 54 & & 52 & & 50 & $\mathrm{a}$ \\
\hline Ginger & 62 & & 61 & & 61 & & 55 & & 50 & $\mathrm{a}$ \\
\hline Tea tree & 62 & & 56 & & 56 & & 55 & & 51 & $\mathrm{a}$ \\
\hline \multicolumn{11}{|l|}{$180 D A S$} \\
\hline Clove & 55 & ns & 55 & ns & 54 & ns & 52 & $a b$ & 52 & $\mathrm{a}$ \\
\hline Lemongrass & 55 & & 54 & & 54 & & 44 & $\mathrm{~b}$ & 31 & b \\
\hline Rosemary & 55 & & 56 & & 55 & & 51 & $a b$ & 50 & $\mathrm{a}$ \\
\hline Eucalyptus & 55 & & 53 & & 52 & & 52 & $a b$ & 52 & $\mathrm{a}$ \\
\hline Ginger & 55 & & 54 & & 54 & & 55 & $\mathrm{a}$ & 52 & $\mathrm{a}$ \\
\hline Tea tree & 55 & & 54 & & 53 & & 54 & $\mathrm{a}$ & 51 & $\mathrm{a}$ \\
\hline
\end{tabular}

Note. *Means followed by the same letter in the column, within each storage period, do not differ statistically by Tukey test at $5 \%$ significance; ns = not significant. 

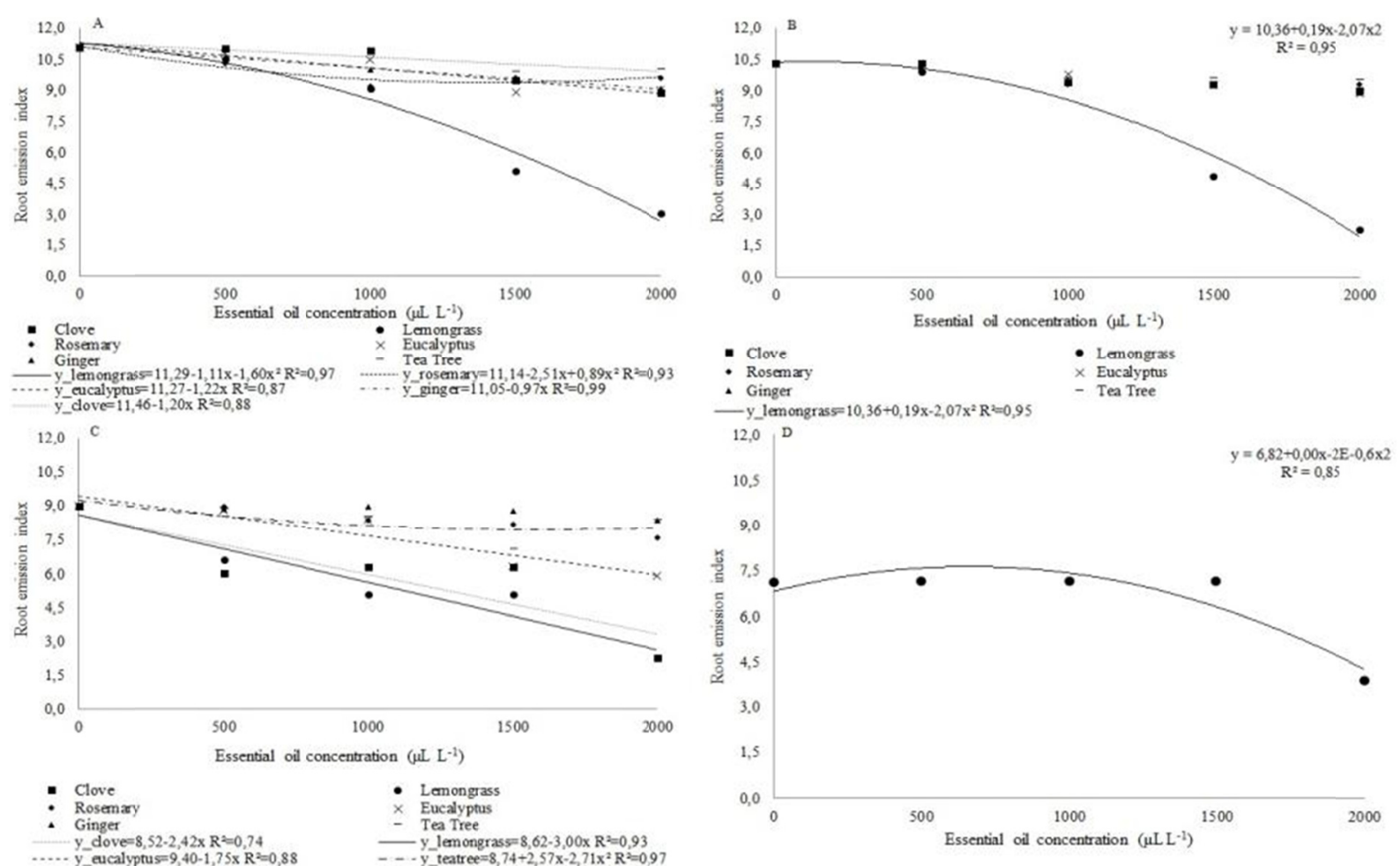

- Clove

Rosemary
Ginger
y dove $=8,52 \cdot 2,42 \times R^{2}=0,74$

- Lanongrass

y_dove=8, 52-2,42x R20,74 - Tea Tree

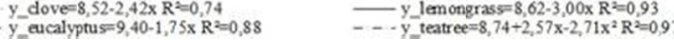

- Lemongras

$\times$ Eucalyptus
- Tea Tree

Figure 4. Regression analysis of root emission index (REI) of coriander seedlings submitted to different concentrations of essential oils in post-harvest (A), 60 (B), 120 (C) and 180 (D) days after storage (DAS)

With increasing concentrations of ginger, eucalyptus and Tea tree essential oils there was a linear reduction in seedling emergence in post-harvest and at 120 DAS. In seeds treated with lemongrass essential oil, the minimum point obtained from the post-harvest equation derivative was $1.162 \mu \mathrm{L} \mathrm{L}^{-1}$, at $120 \mathrm{DAS}$ of $0.399 \mu \mathrm{L} \mathrm{L}^{-1}$ and $180 \mathrm{DAS}$ of $0.392 \mu \mathrm{L} \mathrm{L}^{-1}$ (Figure 5). 

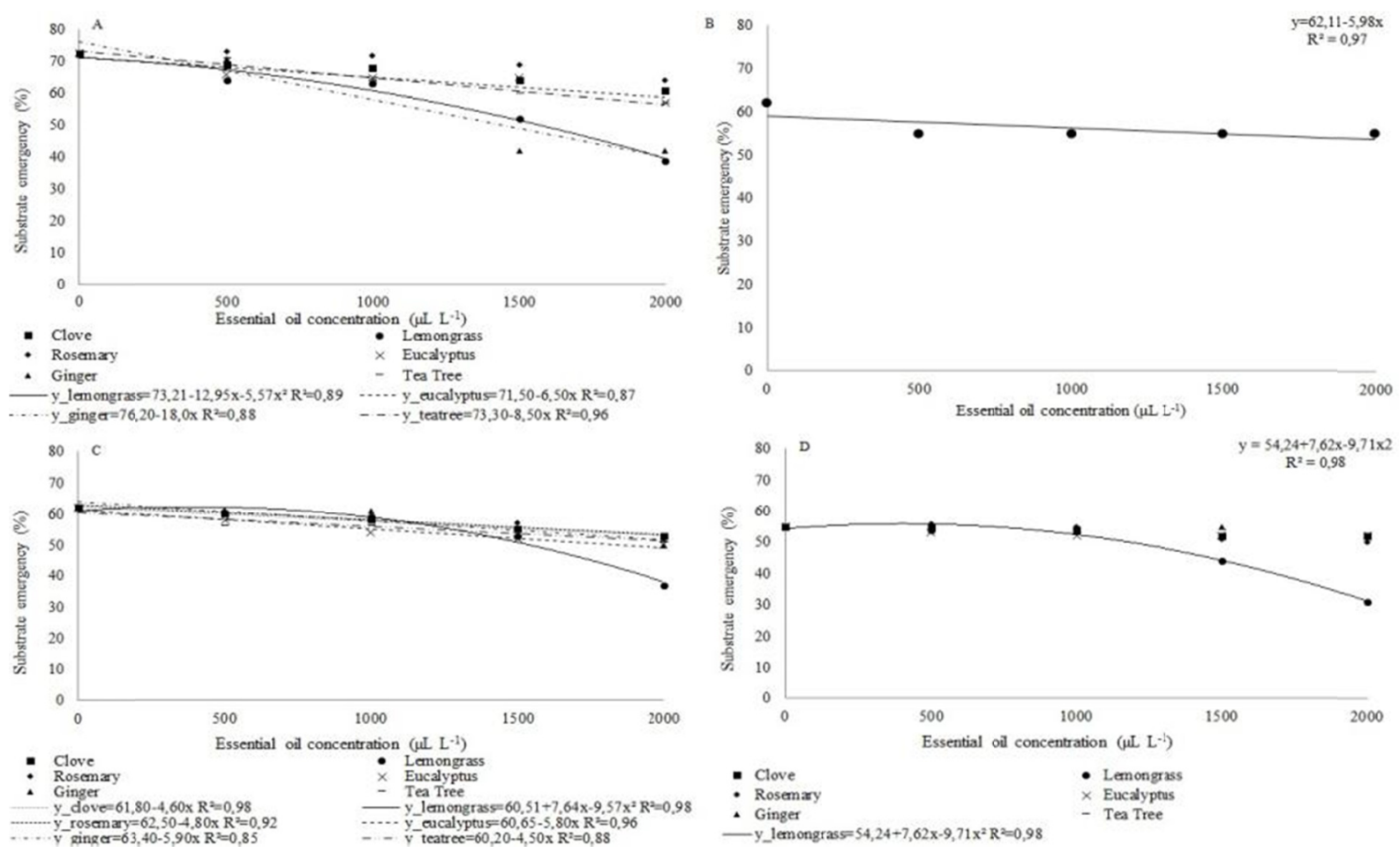

Figure 5. Emergence regression analysis (\%) of coriander seedlings submitted to different concentrations of essential oils in post-harvest (A), 60 (B), 120 (C) and 180 (D) days after storage (DAS)

There was no significant interaction for shoot length (SL), root length (RL) and total length (TL) of coriander seedlings. For shoot length, there were no significant post-harvest differences (Table 7).

After 60 days of storage, seeds treated with clove, lemongrass and eucalyptus essential oils had a statistically lower shoot length than the other treatments. At 120 days of storage, those treated with rosemary and ginger essential oils resulted in a statistically higher shoot length compared to the others, and at 180 days only in the results with essential oil of ginger there was a statistically higher seedling length compared to other treatments. Post-harvest treatment with eucalyptus essential oil increased coriander seedling root length, which was superior to the results obtained with the use of clove and ginger oils. At 60 days, the root length was higher application of rosemary essential oil than clove, lemongrass and eucalyptus (Table 7).

For the total length of coriander seedlings (TL), there were no significant differences between the post-harvest essential oils. At 60 DAS, seeds treated with essential oil of clove showed a significant reduction in TL compared to those treated with other essential oils. This factor was observed up to 180 DAS. At 120 DAS seeds treated with rosemary and ginger essential oils showed higher TL than the others. At 180 DAS only the ginger essential oil caused higher seedling TL than the other essential oils (Table 7).

Regression analyzes indicated that there was a linear reduction of total seedling length with increasing essential oil concentrations up to 120 DAS. The use of essential oils reduced seedling length (Figure 6). 
Table 7. Shoot length (SL), root length (RL) and total length (TL) in centimeters (cm) of coriander seedlings submitted to different concentrations of essential oils in post-harvest, 60, 120 and 180 days after storage (DAS).

\begin{tabular}{|c|c|c|c|c|c|c|}
\hline \multirow{2}{*}{ Essential oil } & \multicolumn{6}{|c|}{ Initial post-harvest } \\
\hline & \multicolumn{2}{|l|}{ SL } & \multicolumn{2}{|l|}{ RL } & \multicolumn{2}{|l|}{$\mathrm{TL}$} \\
\hline Clove & 4.6 & $\mathrm{~ns}$ & 4.9 & $b^{*}$ & 9.5 & ns \\
\hline Lemongrass & 4.4 & & 5.0 & $\mathrm{ab}$ & 9.4 & \\
\hline Rosemary & 4.6 & & 5.6 & $a b$ & 10.2 & \\
\hline Eucalyptus & 4.7 & & 5.8 & $\mathrm{a}$ & 10.5 & \\
\hline Ginger & 4.6 & & 4.8 & $\mathrm{~b}$ & 9.4 & \\
\hline Tea tree & 4.3 & & 5.1 & $a b$ & 9.4 & \\
\hline \multicolumn{7}{|l|}{$60 D A S$} \\
\hline Clove & 2.2 & $\mathrm{c}$ & 1.9 & $\mathrm{~d}$ & 4.1 & $\mathrm{c}$ \\
\hline Lemongrass & 3.0 & $\mathrm{~b}$ & 2.5 & bc & 5.5 & $\mathrm{~b}$ \\
\hline Rosemary & 3.9 & $\mathrm{a}$ & 3.2 & $\mathrm{a}$ & 7.1 & $\mathrm{a}$ \\
\hline Eucalyptus & 2.7 & $\mathrm{~b}$ & 2.3 & $\mathrm{c}$ & 5.0 & $\mathrm{~b}$ \\
\hline Ginger & 3.7 & $\mathrm{a}$ & 2.8 & $a b$ & 6.5 & $\mathrm{a}$ \\
\hline Tea tree & 3.8 & $\mathrm{a}$ & 2.9 & $a b$ & 6.7 & $\mathrm{a}$ \\
\hline \multicolumn{7}{|l|}{$120 D A S$} \\
\hline Clove & 1.8 & $\mathrm{~b}$ & 1.4 & ns & 3.2 & $\mathrm{~b}$ \\
\hline Lemongrass & 2.0 & $\mathrm{~b}$ & 1.4 & & 3.4 & $\mathrm{~b}$ \\
\hline Rosemary & 3.3 & $\mathrm{a}$ & 1.5 & & 4.8 & $\mathrm{a}$ \\
\hline Eucalyptus & 2.1 & $\mathrm{~b}$ & 1.2 & & 3.3 & $\mathrm{~b}$ \\
\hline Ginger & 3.0 & $\mathrm{a}$ & 1.5 & & 4.5 & $\mathrm{a}$ \\
\hline Tea tree & 2.1 & $\mathrm{~b}$ & 1.3 & & 3.4 & $\mathrm{~b}$ \\
\hline \multicolumn{7}{|l|}{$180 D A S$} \\
\hline Clove & 1.4 & $\mathrm{~b}$ & 1.4 & $\mathrm{a}$ & 2.8 & $\mathrm{~b}$ \\
\hline Lemongrass & 1.5 & $\mathrm{~b}$ & 1.0 & $\mathrm{~cd}$ & 2.5 & $\mathrm{~b}$ \\
\hline Rosemary & 1.8 & $\mathrm{~b}$ & 0.9 & $d$ & 2.7 & $\mathrm{~b}$ \\
\hline Eucalyptus & 1.7 & $\mathrm{~b}$ & 1.3 & $a b c$ & 3.0 & $\mathrm{~b}$ \\
\hline Ginger & 2.1 & $\mathrm{a}$ & 1.4 & $a b$ & 3.5 & $\mathrm{a}$ \\
\hline Tea tree & 1.5 & $\mathrm{~b}$ & 1.2 & bcd & 2.7 & $\mathrm{~b}$ \\
\hline
\end{tabular}

Note. *Means followed by the same letter in the column, within each storage period, do not differ statistically by Tukey test at $5 \%$ significance; ns $=$ not significant. 

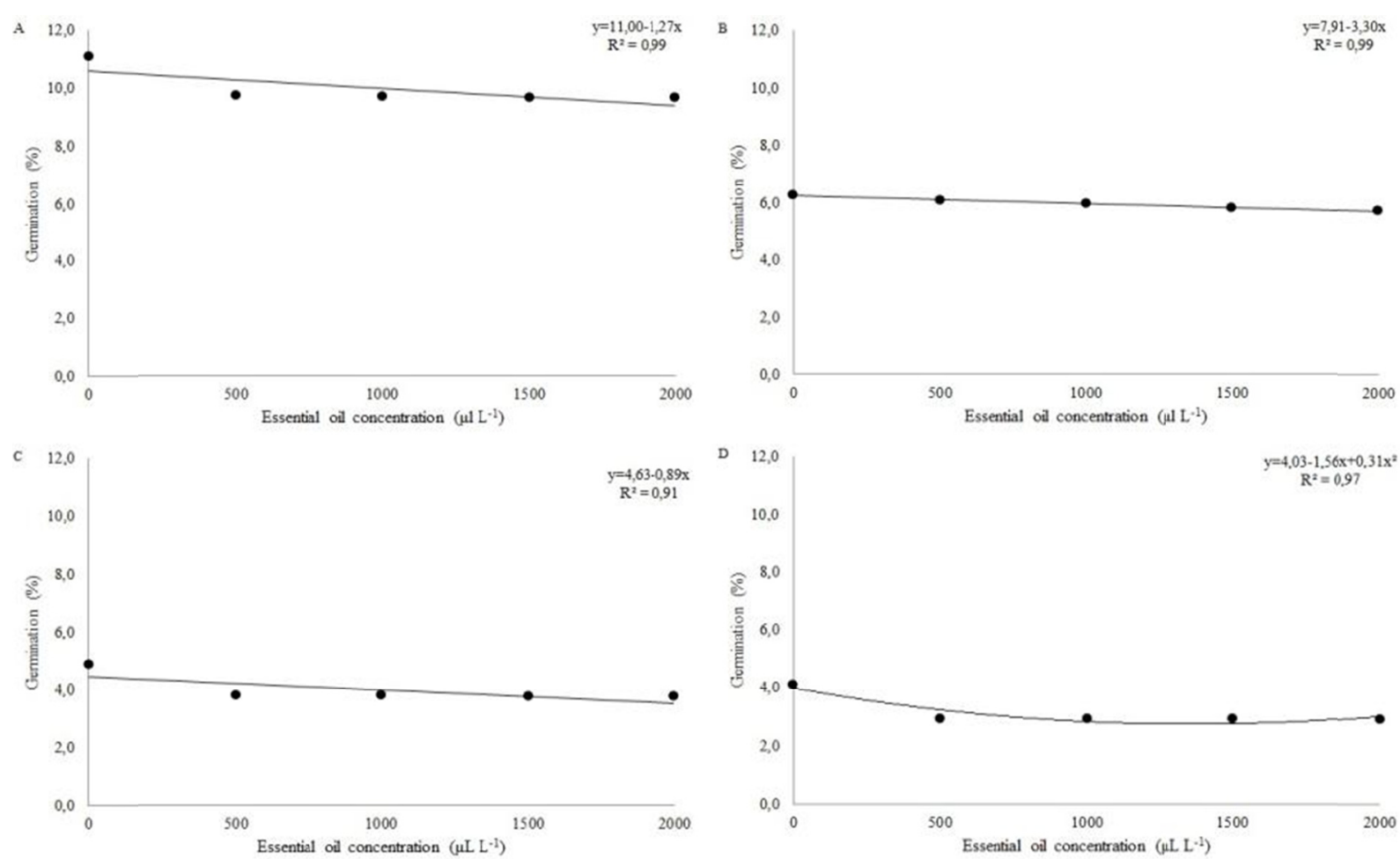

Figure 6. Total length (TL) regression analysis of seedlings submitted to different concentrations of essential oils in post-harvest (A), 60 (B), 120 (C) and 180 (D) days after storage (DAS)

Coriander weed fungi found in the sanity test were mainly Cladosporium sp., Alternaria sp. and Penicillium sp. For the incidence of Cladosporium sp. the interaction was significant between the analyzed factors. In the post-harvest, the seeds of the control treatment presented $92.50 \%$ incidence of Cladosporium sp. Among the essential oils applied to coriander seeds, clove and lemongrass were the most efficient to reduce the incidence of Cladosporium sp. (Table 8). 
Table 8. Incidence of Cladosporium sp. in coriander seeds submitted to the application of different concentrations of essential oils in post-harvest 60, 120 and 180 days after storage (DAS)

\begin{tabular}{|c|c|c|c|c|c|c|c|c|c|c|}
\hline \multirow{3}{*}{ Essential oil } & \multicolumn{10}{|c|}{ Cladosporium sp. (\%) - Initial post-harvest } \\
\hline & \multicolumn{10}{|c|}{ Concentration $\left(\mu 1 \mathrm{~L}^{-1}\right)$} \\
\hline & \multicolumn{2}{|l|}{0} & \multicolumn{2}{|l|}{500} & \multicolumn{2}{|l|}{1.000} & \multicolumn{2}{|l|}{1.500} & \multicolumn{2}{|l|}{2.000} \\
\hline Clove & 92.50 & ns & 88.00 & $\mathrm{~b}^{*}$ & 83.00 & $\mathrm{~b}$ & 58.00 & $\mathrm{c}$ & 67.50 & $\mathrm{c}$ \\
\hline Lemongrass & 92.50 & & 72.00 & $\mathrm{c}$ & 85.50 & $a b$ & 79.50 & $\mathrm{~b}$ & 87.50 & $a b$ \\
\hline Rosemary & 92.50 & & 100.00 & $\mathrm{a}$ & 93.50 & $a b$ & 91.50 & $\mathrm{a}$ & 95.00 & $\mathrm{a}$ \\
\hline Eucalyptus & 92.50 & & 94.50 & $a b$ & 85.50 & $a b$ & 94.00 & $\mathrm{a}$ & 96.50 & $\mathrm{ab}$ \\
\hline Ginger & 92.50 & & 87.50 & $\mathrm{~b}$ & 95.50 & $\mathrm{a}$ & 97.00 & $\mathrm{a}$ & 94.50 & $\mathrm{a}$ \\
\hline Tea tree & 92.50 & & 95.00 & $a b$ & 94.00 & $a b$ & 89.00 & $\mathrm{a}$ & 82.00 & $\mathrm{c}$ \\
\hline \multicolumn{11}{|l|}{$60 D A S$} \\
\hline Clove & 81.50 & $\mathrm{~ns}$ & 84.50 & $a b$ & 80.50 & $a b$ & 85.00 & $\mathrm{a}$ & 51.00 & $\mathrm{c}$ \\
\hline Lemongrass & 81.50 & & 80.50 & $\mathrm{~b}$ & 77.00 & $\mathrm{~b}$ & 75.50 & $\mathrm{~b}$ & 81.50 & $\mathrm{~b}$ \\
\hline Rosemary & 81.50 & & 92.50 & $\mathrm{a}$ & 79.00 & $a b$ & 86.50 & $\mathrm{a}$ & 95.00 & $\mathrm{a}$ \\
\hline Eucalyptus & 81.50 & & 94.50 & $\mathrm{a}$ & 91.00 & $\mathrm{a}$ & 90.50 & $\mathrm{a}$ & 84.50 & $a b$ \\
\hline Ginger & 81.50 & & 96.50 & $\mathrm{a}$ & 89.50 & $\mathrm{a}$ & 94.50 & $\mathrm{a}$ & 94.50 & $\mathrm{a}$ \\
\hline Tea tree & 81.50 & & 94.50 & $\mathrm{a}$ & 90.50 & $\mathrm{a}$ & 91.00 & $\mathrm{a}$ & 87.00 & $\mathrm{ab}$ \\
\hline \multicolumn{11}{|l|}{$120 D A S$} \\
\hline Clove & 95.50 & $\mathrm{~ns}$ & 88.00 & $\mathrm{~b}$ & 83.00 & $\mathrm{~b}$ & 77.00 & $\mathrm{c}$ & 51.00 & $\mathrm{~d}$ \\
\hline Lemongrass & 95.50 & & 67.00 & $\mathrm{~d}$ & 61.00 & $\mathrm{c}$ & 85.00 & $\mathrm{~b}$ & 75.00 & $\mathrm{c}$ \\
\hline Rosemary & 95.50 & & 78.00 & $\mathrm{c}$ & 86.00 & $\mathrm{~b}$ & 86.00 & $\mathrm{~b}$ & 90.50 & $\mathrm{ab}$ \\
\hline Eucalyptus & 95.50 & & 95.00 & $a b$ & 94.00 & $\mathrm{a}$ & 96.00 & $\mathrm{a}$ & 97.50 & $\mathrm{a}$ \\
\hline Ginger & 95.50 & & 97.00 & $\mathrm{a}$ & 98.50 & $\mathrm{a}$ & 98.00 & $\mathrm{a}$ & 98.00 & $\mathrm{a}$ \\
\hline Tea tree & 95.50 & & 94.00 & $a b$ & 94.00 & $\mathrm{a}$ & 93.00 & $\mathrm{a}$ & 89.00 & $\mathrm{~b}$ \\
\hline \multicolumn{11}{|l|}{$180 \mathrm{DAS}$} \\
\hline Clove & 97.50 & ns & 90.50 & $\mathrm{~b}$ & 87.00 & $\mathrm{~b}$ & 87.50 & $\mathrm{~b}$ & 79.50 & $\mathrm{c}$ \\
\hline Lemongrass & 97.50 & & 79.50 & $\mathrm{c}$ & 85.50 & $\mathrm{~b}$ & 83.50 & $\mathrm{~b}$ & 89.50 & $\mathrm{~b}$ \\
\hline Rosemary & 97.50 & & 98.50 & $\mathrm{a}$ & 99.00 & a & 97.00 & $\mathrm{a}$ & 93.50 & $\mathrm{ab}$ \\
\hline Eucalyptus & 97.50 & & 95.00 & $a b$ & 99.00 & $\mathrm{a}$ & 98.50 & $\mathrm{a}$ & 96.50 & $\mathrm{a}$ \\
\hline Ginger & 97.50 & & 96.50 & $a b$ & 97.00 & $\mathrm{a}$ & 100.00 & $\mathrm{a}$ & 100.00 & $\mathrm{a}$ \\
\hline Tea tree & 97.50 & & 98.00 & $\mathrm{a}$ & 95.00 & $\mathrm{a}$ & 94.00 & $\mathrm{a}$ & 96.00 & $\mathrm{a}$ \\
\hline
\end{tabular}

Note. *Means followed by the same letter in the column, within each storage period, do not differ statistically by Tukey test at $5 \%$ significance; ns $=$ not significant.

For coriander seeds the increase of clove essential oil concentration at post-harvest and at 180 DAS caused a linear reduction in the incidence of Cladosporium sp. (Figure 7). 

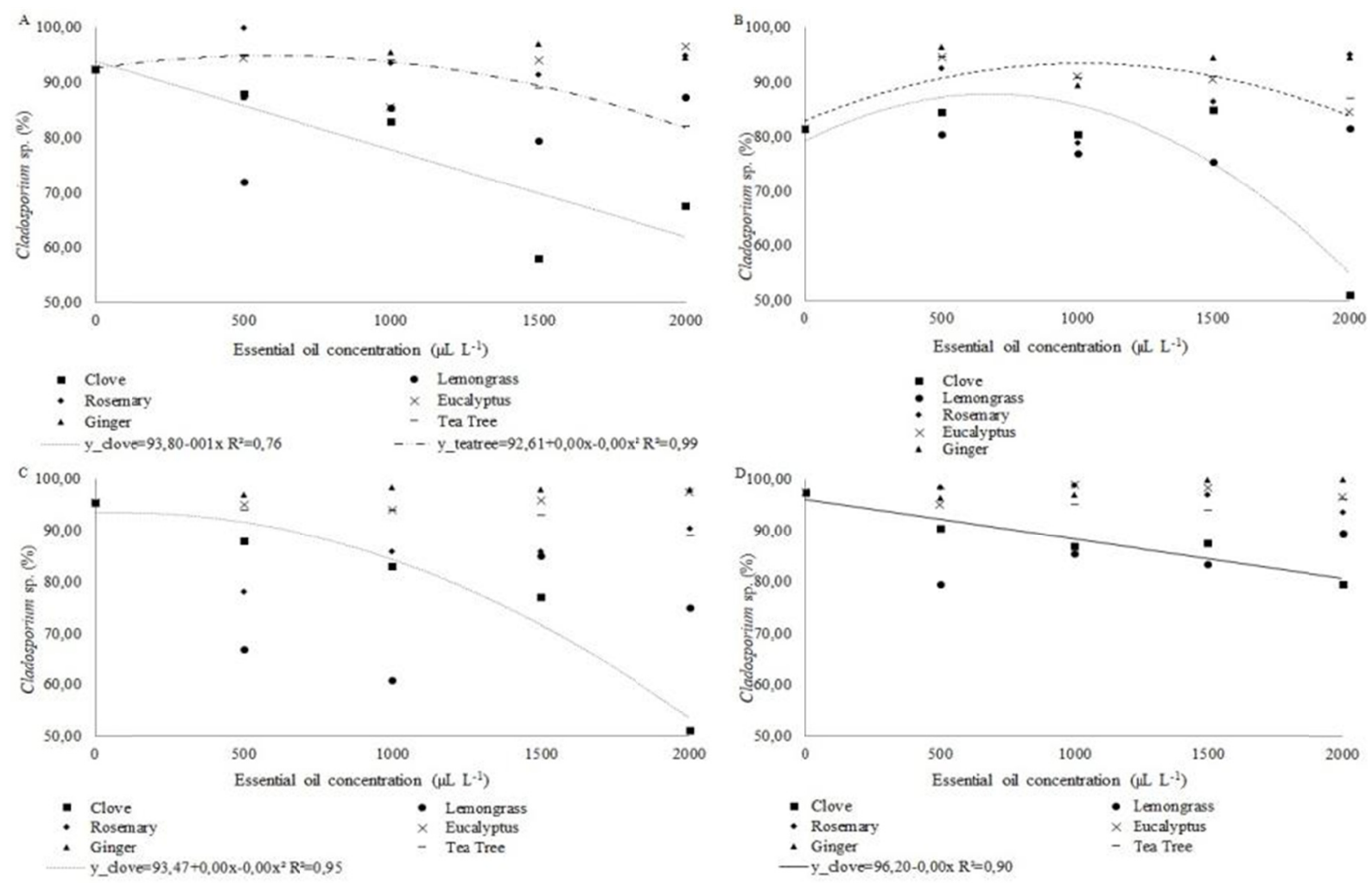

Figure 7. Regression analysis of the incidence of Cladosporium $\mathrm{sp}$. in coriander seeds submitted to different concentrations of essential oils in post-harvest (A), 60 (B), 120 (C) and 180 (D) days after storage (DAS)

For the incidence of Alternaria sp. The interaction was significant between the factors only in post-harvest. Coriander seeds from the control treatment had a 55\% incidence of Alternaria sp. From post-harvest to 60 DAS, Essential oil de clove resulted in a reduction in the incidence of Alternaria sp. in the seeds (Table 9).

Table 9. Incidence and regression analysis of Alternaria sp. in coriander seeds submitted to application of different concentrations of essential oils at post-harvest, 60, 120 and 180 days after storage (DAS)

\begin{tabular}{|c|c|c|c|c|c|c|c|c|c|}
\hline \multirow{3}{*}{ Essential oil } & \multicolumn{9}{|c|}{ Alternaria sp. (\%)-Initial post-harvest } \\
\hline & \multicolumn{9}{|c|}{ Concentration $\left(\mu 1 \mathrm{~L}^{-1}\right)$} \\
\hline & 0 & 500 & & 1.000 & & 1.500 & & 2.000 & \\
\hline Clove & $55.75^{\mathrm{ns}}$ & 19.00 & $\mathrm{c}^{*}$ & 21.00 & $\mathrm{c}$ & 18.50 & $\mathrm{c}$ & 21.50 & $\mathrm{c}$ \\
\hline Lemongrass & 55.75 & 35.50 & $\mathrm{~b}$ & 36.50 & $\mathrm{~b}$ & 33.00 & $\mathrm{~b}$ & 33.00 & $\mathrm{~b}$ \\
\hline Rosemary & 55.75 & 38.00 & $\mathrm{~b}$ & 36.00 & $\mathrm{~b}$ & 36.00 & $\mathrm{ab}$ & 34.50 & $\mathrm{~b}$ \\
\hline Eucalyptus & 55.75 & 47.00 & $\mathrm{a}$ & 47.00 & $\mathrm{a}$ & 43.50 & a & 37.00 & $a b$ \\
\hline Ginger & 55.75 & 56.00 & $\mathrm{a}$ & 55.50 & $\mathrm{a}$ & 44.50 & $\mathrm{a}$ & 32.50 & $\mathrm{~b}$ \\
\hline \multirow[t]{2}{*}{ Tea tree } & 55.75 & 51.00 & $\mathrm{a}$ & 48.75 & $\mathrm{a}$ & 47.00 & $\mathrm{a}$ & 45.50 & $\mathrm{a}$ \\
\hline & \multicolumn{2}{|l|}{60 DAS } & \multicolumn{3}{|c|}{$120 \mathrm{DAS}$} & \multicolumn{3}{|c|}{$180 \mathrm{DAS}$} & \\
\hline Clove & $32.55 \mathrm{c}$ & & & $b$ & & & 32.10 & $\mathrm{bc}$ & \\
\hline Lemongrass & $3.92 \mathrm{c}$ & & & $c$ & & & 28.45 & d & \\
\hline Rosemary & $35.70 \mathrm{bc}$ & & & $\mathrm{c}$ & & & 31.50 & bcd & \\
\hline Eucalyptus & $43.70 \mathrm{a}$ & & & $a$ & & & 39.60 & $\mathrm{a}$ & \\
\hline Ginger & $37.65 \mathrm{~b}$ & & & $b$ & & & 33.25 & b & \\
\hline Tea tree & $34.15 \mathrm{bc}$ & & & $b c$ & & & 29.60 & $\mathrm{~cd}$ & \\
\hline
\end{tabular}

Note. ${ }^{*}$ Means followed by the same letter in the column do not differ statistically from each other by the Tukey test at $5 \%$ significance; $n s=$ not significant. 
There was a linear reduction in the beginning of Alternaria sp. post-harvest with the use of eucalyptus essential oil in the seeds, with the increase of concentration. From 60 to 180 DAS the incidence of Alternaria sp. The increase in essential oil concentrations was represented by the quadratic model (Figure 8).
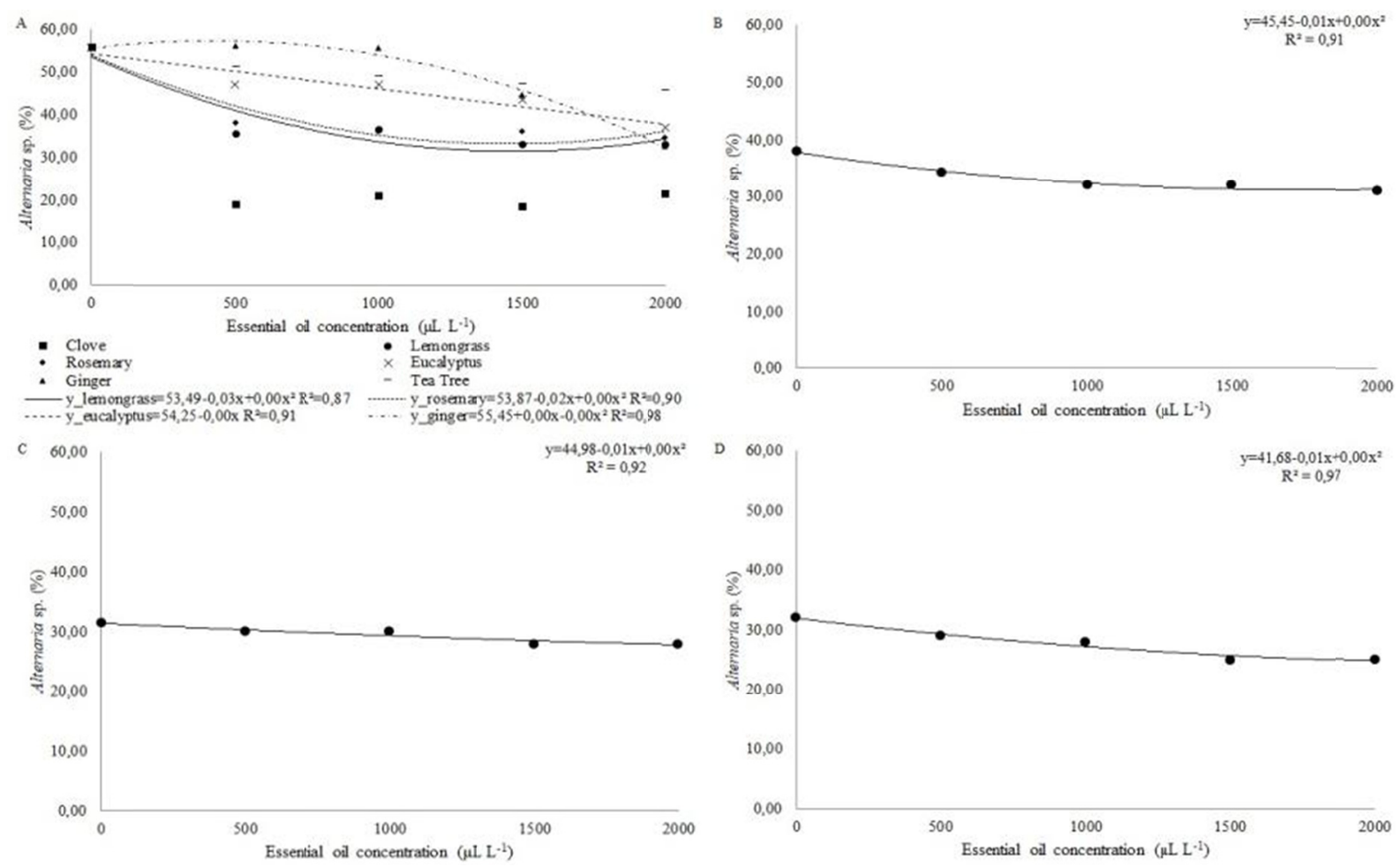

Figure 8. Regression analysis of the incidence of Alternaria sp. in coriander seeds submitted to the application of different concentrations of essential oils in the post-harvest (A), 60 (B), 120 (C) and 180 (D)

At 120 DAS, seeds treated with lemongrass and rosemary essential oils had a statistically significant reduction in the incidence of Alternaria sp. There was no significant interaction between essential oil and concentration factors for incidence of Penicillium sp. until 120 DAS. There was a significant reduction in the incidence of Penicillium sp. 180 DAS with increasing concentrations of the essential oils of lemongrass, eucalyptus, Tea tree, ginger and rosemary (Table 10). 
Table 10. Incidence of Penicillium sp. in coriander seeds submitted to the application of different concentrations of essential oils in post-harvest 60,120 and 180 days after storage (DAS)

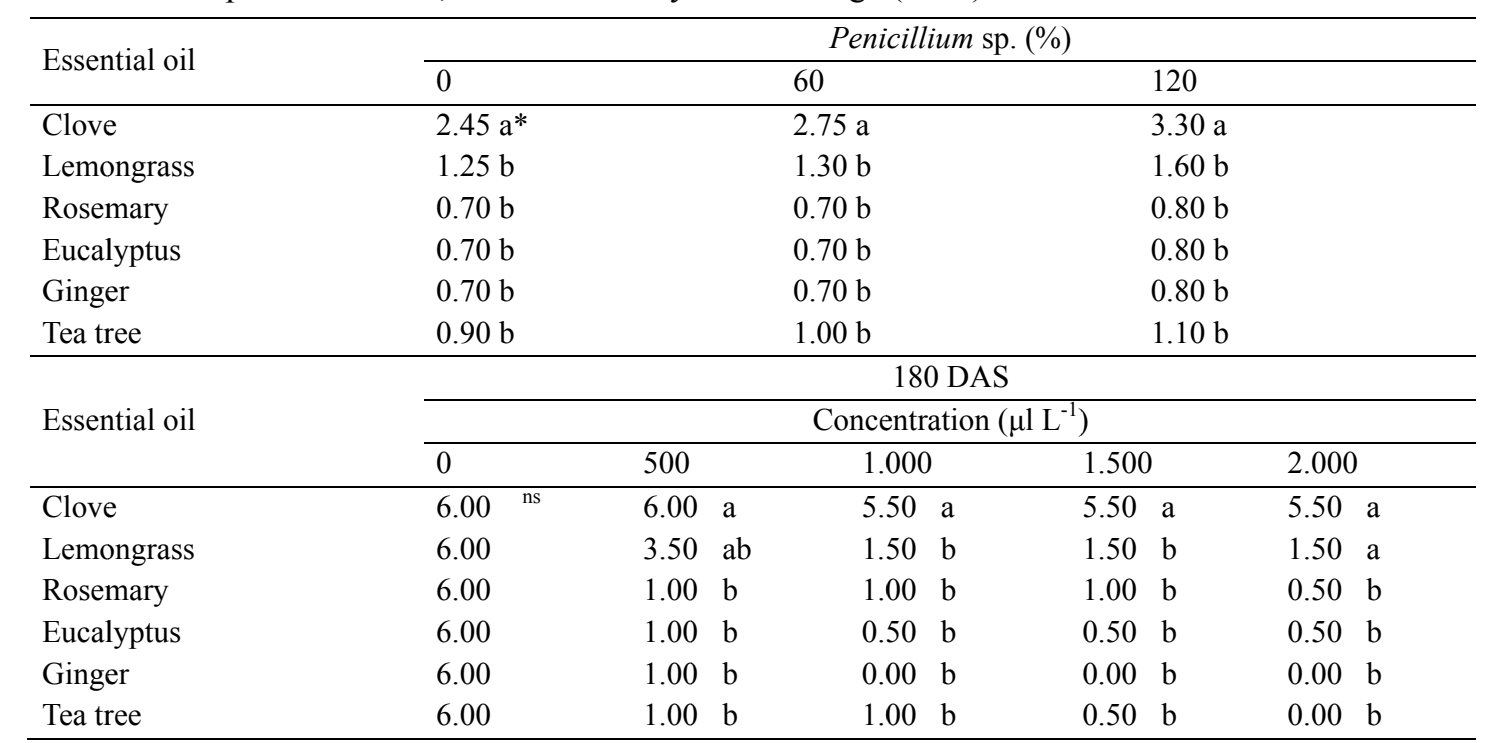

Note. * Means followed by the same letter in the column do not differ statistically from each other by the Tukey test at $5 \%$ significance; $\mathrm{ns}=$ not significant.

With increasing concentrations of essential oils, there was adaptation to the quadratic model for the incidence of Penicillium sp. in relation to the control treatment, at all times evaluated (Figure 9).
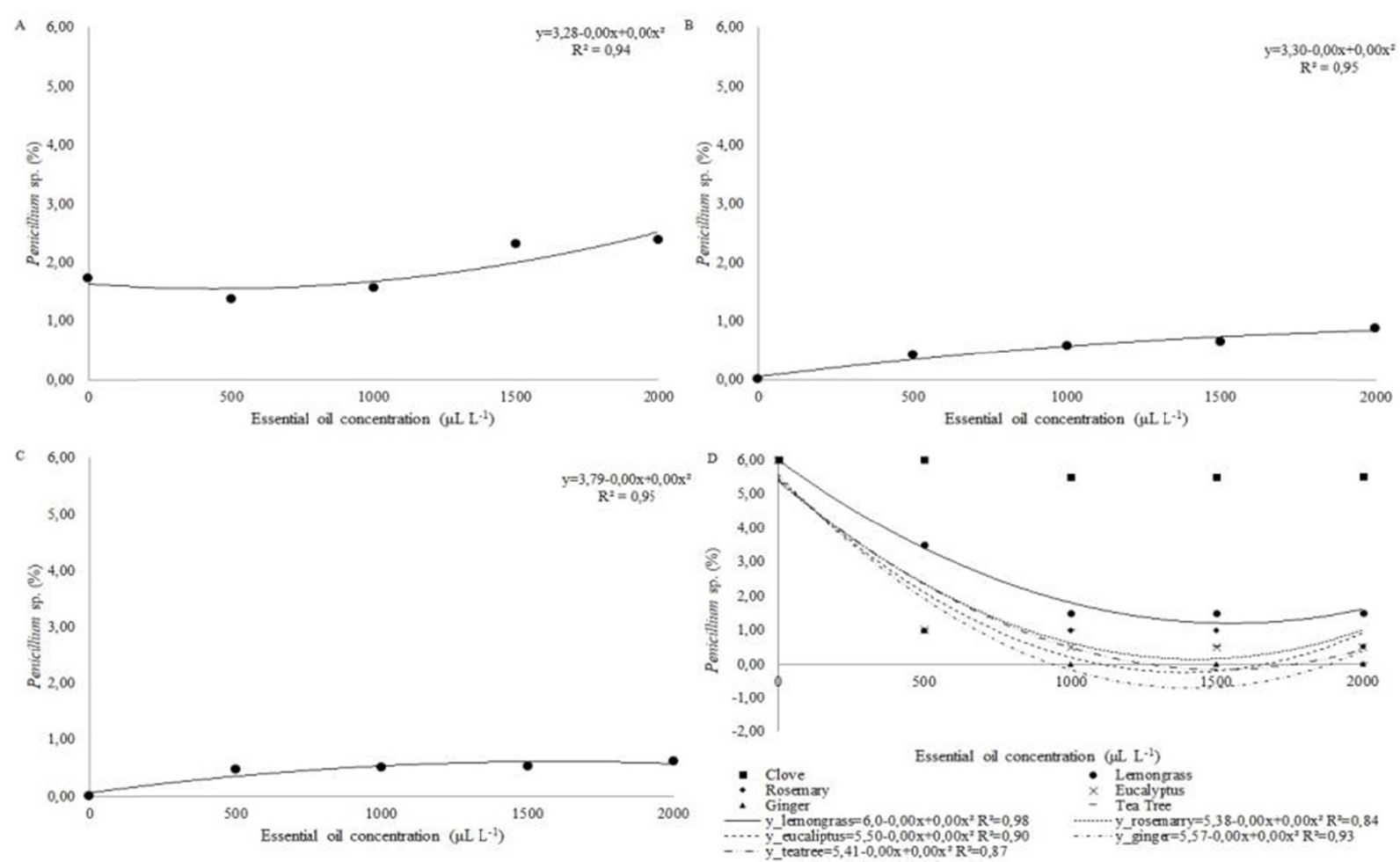

Figure 9. Regression analysis of the incidence of Penicillium sp. in coriander seeds submitted to different concentrations of essential oils in post-harvest (A), 60 (B), 120 (C) and 180 (D) days after storage (DAS) 


\section{Discussion}

Seed germination was $76 \%$ in post-harvest for control treatment seeds, which are common results for coriander seeds, as stated by Pereira et al. (2005). The seeds have problems related to vigor, plant establishment and disease. According to regulation $\mathrm{N}^{0} 457$ of December 18, 1986, coriander seeds must have a minimum germination of $60 \%$ for seed distribution, transportation and trade in the country (Brasil, 1986).

According to Miranda et al. (2015) seed germination or seedling development of certain species has influence of chemical alleles contained in vegetable oils. The authors concluded in their study that lemongrass essential oil reduced the germination and vigor of lettuce seeds, which can be attributed to the contents of the major constituents, citral and eugenol. The essential oil of lemongrass presented $48.7 \%$ concentration of citral, isomer of geranial (Table 1).

Linalool compounds present in lemongrass and rosemary essential oils, eugenol, present in clove and rosemary essential oils and cineol present in rosemary, Tea tree and eucalyptus essential oils, may influence the reduction of the primary root length of the seedling (Table 1). Such effect was also observed by Gomes et al. (2016) at concentrations starting at $1.5 \mathrm{~mL} \mathrm{~L}^{-1}$ with clove essential oil.

According to Nishida et al. (2005) five volatile monoterpenes, eucalyptol, $\alpha$ and $\beta$-pinene (present in eucalyptus essential oil), camphene (present in ginger, lemongrass and rosemary essential oil (EO)) and camphor (present in rosemary EO), showed inhibit the development of Brassica campestris roots by interfering in the synthesis of organelle and nuclear DNA within meristematic cells. Others monoterpenes, 1,8-cineole (present in the eucalyptus, Tea tree and rosemary EO) timol, geraniol (present in the EO of ginger) and camphor inhibited corn root growth and induced oxidative stress (Zunino \& Zygadlo, 2004).

Among the essential oils used lemongrass reduced the physiological quality of seeds. This oil has in its geranial and neral composition (Table 1). The geranial is a monoterpene, trans-isomer of citral. According to Chaimovitsh et al. (2012) seed germination and seedling development are inhibited in the presence of citral, which causes damage to the interphase cell microtubules of both plants and animals. Granã et al. (2013) evaluating the effect of citral on the root development of Arabidopsis thaliana, showed changes in cell division, thickening of the cell wall and reduced intercellular communication, confirming the compound's phytotoxicity. Therefore, the effects of Lemongrass Essential Oil verified in this work can be attributed to the presence of geranial and neral, which presented $48.7 \%$ and $42.2 \%$ of these substances respectively (Table 1 ).

Brito et al. (2012) evaluating corn seeds of cultivar XGN5320, found that eucalyptus essential oil, in concentrations of 5, 10 and $15 \%$, reduced seed germination, demonstrating that it is essential to evaluate the use of these oils through toxicity tests, because these oils have some biological activity and applications with inadequate concentration cause the abnormal development of plants. The inhibition of seed germination and seedling development were also observed by Shokouhian, Habibi \& Agahi (2016). The authors verified for lettuce seeds (Lactuca sativa) that the application of essential oils of rosemary (Rosmarinus officinalis), thyme (Thymus vulgaris) and anise (Pimpinellaanisum) significantly reduced seed germination.

Abbaszadeh et al. (2014) observed that the most potent inhibitory activity of thymol, carvacrol, eugenol and menthol was found for Cladosporium sp. Gomes et al. (2016) found a maximum reduction in the percentage incidence of Cladosporium sp., from concentrations of $1.53 \mathrm{~mL} \mathrm{~L}^{-1}$ to $2.0 \mathrm{~mL} \mathrm{~L}^{-1}$ with clove essential oils and basil. The same authors observed a significant reduction in the incidence of Penicillium sp. In the present work, these results were not observed with clove essential oil. According to Menezes et al. (2017) the genus Cladosporium sp. comprises a large number of fungi with worldwide distribution and which are among the most common environmental fungi. They are often isolated as contaminants, however, some species are pathogenic and toxigenic for humans.

Hillen et al. (2012) found 100\% inhibition in the mycelial growth of Alternaria sp. using concentrations of essential clove oil with $100,200,500$ and $1.000 \mu \mathrm{L} \mathrm{L}^{-1}$, and at concentrations of 20,40 and $60 \mu \mathrm{L}^{-1}$ the inhibition gradually decreased. In the present work, these results were not observed with clove essential oil. Matusinsky et al. (2015) found a reduction in mycelial growth of isolated species of the genera Penicillium sp. and Fusarium sp. using a dose of $10.0 \mu \mathrm{L} \mathrm{L}^{-1}$ of the essential oils of rosemary (Rosmarinus officinalis) and thyme (Thymus vulgaris).

Clove oil used in this study has more than $80 \%$ eugenol, which is considered its main component (Table 1). Castro et al. (2005) found that clove essential oil was promising, significantly reducing the fungal growth of Alternaria alternata. 
The results found in the present study correlating the chemical constitution and the allelopathic activity of each essential oil and its major constituents corroborate the observations made by Souza Filho et al. (2010), who stated that the effects of essential oils on seedling germination and vigor cannot be generalized and can be explained in an individualized way considering their main chemical constituents.

It is concluded that the essential oils of lemongrass, eucalyptus, ginger, rosemary and tea tree at concentrations above $500 \mu \mathrm{L} \mathrm{L}^{-1}$ reduce the germination and vigor of coriander seeds. Clove and rosemary essential oils at a concentration of $500 \mu \mathrm{L} \mathrm{L}^{-1}$, eucalyptus at a concentration of $1.500 \mu \mathrm{L} \mathrm{L}^{-1}$ and ginger $2.000 \mu \mathrm{L} \mathrm{L}^{-1}$ are efficient for reducing Alternaria sp. in coriander seeds. Coriander seeds can be treated with clove and rosemary essential oils at concentrations up to $500 \mu \mathrm{L} \mathrm{L}^{-1}$, without significantly affecting germination, reducing post-harvest incidence of Alternaria sp. Storage of coriander seeds treated with essential oils is not feasible.

\section{Acknowledgements}

We would like to thank Mokiti Okada Foundation for providing Coriander seeds.

\section{References}

Abbaszadeh, S., Sharifzadeh, A., Shokri, H., Khosravi, A. R., \& Abbaszadeh, A. (2014). Antifungal efficacy of thymol, carvacrol, eugenol and menthol as alternative agents to control the growth of food-relevant fungi. Journal de Mycologie Médicale, 24(2), e51-e56. https://doi.org/10.1016/j.mycmed.2014.01.063

Amini, L., Soudi, M. R., Saboora, A., \& Mobasheri, H. (2018). Effect of essential oil from Zataria multiflora on local strains of Xanthomonas campestris: An efficient antimicrobial agent for decontamination of seeds of Brassica oleracea var. Capitata. Scientia Horticulturae, 236, 256-264. https://doi.org/10.1016/j.scienta. 2018.03.046

Andrés, M. F., González-Coloma, A., Sanz, J., Burillo, J., \& Sainz, P. (2012). Nematicidal activity of essential oils: a review. Phytochemical Review, 11, 371-390. https://doi.org/10.1007/s11101-012-9263-3

Angioni, A., Barra A., Cereti, E., Barile, D., Coisson, J. D., Arlorio, M., ... Cabras, P. (2004). Chemical composition, plant genetic differences, antimicrobial and antifungal activity investigation of the essential oil of Rosmarinus officinalis L. Journal of Agricultural and Food Chemistry, 52(11), 3530-3535. https://doi.org/10.1021/jf049913t

Aragão, F. B., Palmieri, M. J., Ferreira, A., Costa, A. V., Queiroz, V. T., Pinheiro, P. F., \& Andrade-Vieira, L. F. (2015). Phytotoxic and cytotoxic effects of Eucalyptus essential oil on Lactuca sativa L. Allelopathy Journal, 35(1), 259-272. https://doi.org/0971-4693/94 Euro 10.00

Bakkali, F., Averbeck, S., Averbeck, D., \& Idaomar, M. (2008). Biological effects of essencial oils: a review. Food Chemical Toxicology, 46, 446-475. https://doi.org/10.1016/j.fct.2007.09.106

Boukaew, A., Prasertsan, P., \& Sattayasamitsathit, S. (2017). Evaluation of antifungal activity of essential oils against aflatoxigenic Aspergillus flavus and their allelopathic activity from fumigation toprotect maize seeds during storage. Industrial Crops and Products, 97, 558-566. https://doi.org/10.1016/j.indcrop. 2017.01.005

Brasil. (1986). Portaria $N^{o} 457$, de 18 de dezembro de 1986. Ministério da Agricultura, Pecuária e Abastecimento. Retrieved from April 20, 2018, from http://www.abcsem.com.br/docs/portaria-n457 estabelece.pdf

Brasil. (2009a). Regras para análise de sementes. Ministério da Agricultura, Pecuária e Abastecimento. Retrieved from http://www.agricultura.gov.br/assuntos/insumos-agropecuarios/arquivos-publicacoes-insum os/2946_regras_analise_sementes.pdf

Brasil. (2009b). Manual de análise sanitária de sementes. Ministério da Agricultura, Pecuária e Abastecimento. Retrieved from https://www.abrates.org.br/files/manual-de-analise-sanitaria-de-sementes.pdf

Brito, D. R., Ootani, M. A., Ramos, A. C. C., Sertão, W. C., \& Aguiar, R. W. de S. (2012). Efeito dos óleos de citronela, eucalipto e composto citronelal sobre microflora e desenvolvimento de plantas de milho. Journal of Biotechnology and Biodiversity, 3(4), 184-192. https://doi.org/10.20873/jbb.uft.cemaf.v3n4.brito

Castro, C., Silva, M. L. da, Pinheiro, A. L., \& Jacovine, L. A. G. (2005). Análise econômica do cultivo e extração do óleo essencial de Melaleuca alternifolia Chell. Revista Árvore, 29(2), 241-249. https://doi.org/ 10.1590/S0100-67622005000200007 
Chaimovitsh, D., Rogovoy Stelmakh, O., Altshuler, O., Belausov, E., Abu-Abied, M., Rubin, B., ... Dudai, N. (2012). The relative effect of citral on mitotic microtubules in wheat roots and BY2 cells. Plant Biology, 14, 354-364. https://doi.org/10.1111/j.1438-8677.2011.00511.x

Filgueira, F. A. R. (2008). Novo manual de olericultura: Agrotecnologia moderna na produção e comercialização de hortaliças (3rd ed.). Viçosa, MG: UFV.

Flávio, N. S. D. S., Sales, N. de. L. P., Aquino, C. F., Soares, E. P. S., Aquino, L. F. S., \& Catão, H. C. R. M. (2014). Qualidade sanitária e fisiológica de sementes de sorgo tratadas com extratos aquosos e óleos essenciais. Semina: Ciências Agrárias, 35(1), 7-20. https://doi.org/10.5433/1679-0359.2014v35n1p7

Gomes, R. S. S., Nunes, M. C., Nascimento, L. C., Souza, J. O., \& Porcino, M. M. (2016). Eficiência de óleos essenciais na qualidade sanitária e fisiológica em sementes de feijão-fava (Phaseolus lunatus L.). Revista Brasileira de Plantas Medicinais, 18(1), 279-287. https://doi.org/10.1590/1983-084X/15_117

Granã, E., Sotelo, T., Díaz-Tielas, C., Araniti, F., Krasuska, U., Bogatek, R., ... Sánchez-Moreiras, A. M. (2013). Citral induces auxin and ethylene-mediated malformations and arrests cell division in Arabidopsis thaliana roots. Journal of Chemical Ecology, 39(2), 271-282. https://doi.org/10.1007/s10886-013-0250-y.

Hillen, T., Schwan-Estrada, K. R. F., Mesquini, R. M., Cruz, M. E. S., Stangarlin, J. R., \& Nozaki, M. (2012). Atividade antimicrobiana de óleos essenciais no controle de alguns fitopatógenos fúngicos in vitro e no tratamento de sementes. Revista Brasileira de Plantas Medicinais, 14(3), 439-445. https://doi.org/10.1590/ S1516-05722012000300003

Joly, A. B. (2002). Botânica: Introdução a taxonomia vegetal (13th ed.). São Paulo: Companhia Editora Nacional.

Kamazeri, T. S., Samah, O. A., Taher, M., Susanti, D., \& Qaralleh, H. (2012). Antimicrobial activity and essential oils of Curcuma aeruginosa, Curcuma mangga, and Zingiber cassumunar from Malaysia. Asian Pacific Journal of Tropical Medicine, 5(3), 202-209. https://doi.org/10.1016/S1995-7645(12)60025-X

Maguire, J. D. (1962). Speed germination-aid index in selection and evaluation seedlings vigor. Crop Science, 1(2), 161-162. https://doi.org/10.2135/cropsci1962.0011183X000200020033x

Matusinsky, P., Zouhar, M., Pavela, R., \& Novy, P. (2015). Antifungal effect of five essential oils against important pathogenic fungi of cereals. Industrial Crops and Products, 67, 208-2015. https://doi.org/ 10.1016/j.indcrop.2015.01.022

Menezes, C. P. de, Pérez, A. L. A. de L., \& Lima, E. de O. (2017). Cladosporium spp: Morfologia, infecções e espécies patogênicas. Acta Brasiliensis, 1(1), 23-27. https://doi.org/10.22571/Actabra1120176

Miranda, C. A. S. F., Cardoso, M. das G., Carvalho, M. L. M., Machado, S. M. F., Gomes, M. de S., Santiago, J. de A., \& Teixeira, M. L. (2015). Atividade alelopática de óleos essenciais de plantas medicinais na germinação e vigor de aquênios de alface. Semina: Ciências Agrárias, 36(3), 1783-1798. https://doi.org/ 10.5433/1679-0359.2013v34n2p485

Nascimento, W. M., \& Pereira, R. S. (2007). Controle de qualidade de sementes de hortaliças. Retrieved May 10, 2018, from http://www.abhorticultura.com.br/downloads/Warley-2_Controle_qual_sem_\%20hort.pdf

Nascimento, W. M., Pereira, R. S., Freitas, R. A. de, Blumer, L., \& Muniz, M. F. B. (2006). Colheita e armazenamento de sementes de coentro. Pesquisa Agropecuária Brasileira, 41(12), 1793-1801. https://doi.org/10.1590/S0100-204X2006001200015

Nerilo, S. B., Rocha, G. H. O., Tomoike, C., Mossini, S. A. G., Grespan, R., Mikcha, J. M. G., \& Machinski Jr., M. (2016). Antifungal properties and inhibitory effects upon aflatoxin production by Zingiber officinale essential oil in Aspergillus flavus. International Journal of Food Science \& Technology, 51, $286-292$. https://doi.org/10.1111/ijfs. 12950

Nishida, N. Tamotsu, S., Nagata, N., Saito, C., \& Sakai, A. (2005). Allelopathic effects of volatile monoterpenoids produced by Salvia leucophylla: inhibition of cell proliferation and DNA synthesis in the root apical meristem of Brassica campestris seedlings. Journal of Chemical Ecology, 31(5), 1187-1203. https://doi.org/10.1007/s10886-005-4256-y

Pereira, R. S., Muniz, M. F. B., \& Nascimento, W. M. (2005). Aspectos relacionados à qualidade de sementes de coentro. Horticultura Brasileira, 23(3), 703-706. https://doi.org/10.1590/S0102-05362005000300002 
Rochete, F., Engelen, M., \& Vanden Bossche, H. (2003). Antifungal agents of use in animal health-practical applications. Journal Veterinary Pharmacology and Therapy, 26(1), 31-53. https://doi.org/10.1046/j.13652885.2003.00457.x

Shokouhian, A., Habibi, H., \& Agahi, K. (2016). Allelopatic effects of some medicinal plant essential oils on plant seeds germination. Journal of Bioscience and Biotechnology, 5(1), 13-17. http://www.jbb.uni-plovdiv.bg/ documents/27807/1703624/jbb_2016-5(1)-pages_13-17.pdf

Souza Filho, A. P. S., Gurgel, E. S. C., Queiroz, M. S. M., \& Santos, J. U. M. (2010). Atividade alelopática de extratos brutos de três espécies de Copaifera (Leguminosae-Caesalpinioideae). Planta Daninha, 28(4), 743-751. https://doi.org/10.1590/S0100-83582010000400006

Taiz, L., \& Zeiger, E. (2013). Fisiologia vegetal (5. ed., p. 918). Artmed.

Tyagi, A., \& Malik, A. (2011). Antimicrobial potential and chemical composition of Eucalyptus globulus oil in liquid and vapour phase against food spoilage microorganisms. Food Chemistry, 126, 228-235. https://doi.org/10.1016/j.foodchem.2010.11.002

Vieira, R. D., \& Carvalho, N. M. de. (1994). Testes de vigor baseados na avaliação das plântulas. In J. Nakagawa (Ed.), Testes de vigor em sementes (pp. 49-86). Jaboticabal, SP: Funep.

Wanderley Junior, L. J. G., \& Nascimento, W. M. (2010). Produção de sementes de coentro. Brasília: Embrapa Hortaliças.

Xavier, M. V. A., Brito, S. S. S., Oliveira, C. R. F., Matos, C. H. C., \& Pinto, M. A. D. S. C. (2012). Óleo essencial de Baccharis trimera (Less.) DC. sobre o potencial fisiológico de sementes de feijão caupi. Revista Brasileira de Plantas Medicinais, 14, 214-217. https://doi.org/10.1590/S1516-05722012000500015

Zunino, M. P., \& Zygadlo, J. A. (2004). Effect of monoterpenes on lipid oxidation in maize. Planta, 219(2), 303-309. https://doi.org/10.1007\%2Fs00425-004-1216-7

\section{Copyrights}

Copyright for this article is retained by the author(s), with first publication rights granted to the journal.

This is an open-access article distributed under the terms and conditions of the Creative Commons Attribution license (http://creativecommons.org/licenses/by/4.0/). 